\title{
Hyperinsulinaemic Hypoglycaemia
}

Authors

Affiliations

\section{B. Arya ${ }^{1}$, Z. Mohammed ${ }^{1}$, O. Blankenstein ${ }^{2}$, P. De Lonlay ${ }^{3}$, K. Hussain}

${ }^{1}$ London Centre for Paediatric Endocrinology and Metabolism, Great Ormond Street Hospital for Children NHS Trust and The Institute of Child Health, University College London, London, UK

Department of Endocrinology, Charité-University Medicine, Berlin, Germany

Reference Center for Inherited Metabolic Diseases, Université Paris-Descartes, Institute Imagine, Paris, France
Key words

congenital hyperinsulinism

- hyperinsulinaemic hypoglycaemia

- insulinoma received 02.09.2013

accepted 09.01.2014

\section{Bibliography}

DOI http://dx.doi.org/

10.1055/s-0034-1367063

Published online:

February 20, 2014

Horm Metab Res 2014;

46: 157-170

(c) Georg Thieme Verlag KG

Stuttgart · New York

ISSN 0018-5043

\section{Correspondence}

\section{Dr. K. Hussain}

Developmental Endocrinology

Research Group

Molecular Genetics Unit Institute of Child Health University College London 30 Guilford Street

London WC1N 1EH UK

Tel.: + 44/20/7 9052128

Fax: + 44/20/7 4046191

Khalid.Hussain@ucl.ac.uk

\begin{abstract}
$\nabla$

Insulin secretion from pancreatic $\beta$-cells is tightly regulated to maintain fasting blood glucose level between $3.5-5.5 \mathrm{mmol} / \mathrm{l}$. In hyperinsulinaemic hypoglycaemia $(\mathrm{HH})$ insulin secretion becomes unregulated so that insulin secretion persists despite low blood glucose levels. $\mathrm{HH}$ can be due to a large number of causes and recent advances in genetics have begun to provide novel insights into the molecular mechanisms of HH. Defects in
\end{abstract}

\section{Introduction \\ $\nabla$}

Hyperinsulinaemic hypoglycaemia $(\mathrm{HH})$ is due to the unregulated secretion of insulin in the presence of hypoglycaemia. HH occurs in all age groups (neonates, children and adults), but due to different mechanisms. In the newborn and infancy periods it is a major cause of persistent and recurrent hypoglycaemia associated with hypoglycaemic brain injury.

The biochemical basis of the HH involves dysregulated insulin secretion with defects in glucose counter regulatory hormones [1-3]. The unregulated insulin secretion drives glucose into the insulin sensitive tissues especially skeletal muscle, adipose tissue and liver causing profound hypoglycaemia. This is compounded by the fact that insulin simultaneously inhibits glycogenolysis (glycogen breakdown), gluconeogenesis (glucose production from non-carbohydrate sources), lipolysis and ketogenesis. The normal physiological glucagon and cortisol counter-regulatory hormonal response to hypoglycaemia are blunted in the newborn period further exacerbating the hypoglycaemia $[2,3]$. This biochemical milieu is a recipe for depriving the brain of its most important fuel namely glucose. This brain glucopaenia is accompanied by the lack of alternative substrates such as ketone bodies and lactate. It is under these conditions that the risk of brain damage is highest. key genes involved in regulating insulin secretion have been linked to $\mathrm{HH}$. The most severe forms of $\mathrm{HH}$ are clinically observed in the newborn period whereas in adults an insulinoma is the commonest cause of $\mathrm{HH}$. This review provides an overview on the molecular mechanisms leading to $\mathrm{HH}$ in children and adults, it describes the clinical presentation and diagnosis, and finally the treatment options for the different forms of $\mathrm{HH}$ are discussed.

In the newborn and infancy periods $\mathrm{HH}$ can be either congenital or secondary to certain risk factors (such as intrauterine growth retardation) [4]. Congenital $\mathrm{HH}$ involves either defects in the genes $A B C C 8$ and KCNJ11 (encoding for the 2 proteins SUR1 and KIR6.2 of the pancreatic $\beta$-cell $K_{\text {ATP }}$ channel, respectively), or abnormalities in the enzymes glucokinase, glutamate dehydrogenase and Short Chain Acyl-CoA Dehydrogenase (SCHAD) [5-10]. Mutations in ABCC8/KCNJ11 have been reported to account for $1 / 3^{\text {rd }}$ to $2 / 3^{\text {rd }}$ of the causes of congenital HH in large series of patients $[11,12]$. Mutations in GLUD1 are the second commonest cause, responsible for approximately $5 \%$ of patients. Other known genes altogether account for less than $4 \%$ of patient with congenital $\mathrm{HH}$ $[11,12]$. Loss of function mutations in the genes $A B C C 8$ and KCNJ11 cause the most severe forms of $\mathrm{HH}$, which is usually medically unresponsive.

Histologically, $\mathrm{HH}$ can be classified into 2 broad categories: diffuse (affecting the whole pancreas) and focal (localised to a single region of pancreas) disease [13]. Recent development, flourine-18F 3,4-dihydroxyphenylalanine position emission tomography ( ${ }^{18} \mathrm{~F}$-DOPA-PET) scan, helps to differentiate focal from diffuse disease and accurately localises the focal lesion preoperatively [14]. With the advent of ${ }^{18} \mathrm{~F}$-DOPA-PET scan and laparoscopic surgery, the clinical approach has changed dramatically. 
In adults, apart from an insulinoma, $\mathrm{HH}$ has been reported with several conditions including insulin autoimmune syndrome, non-insulinoma pancreatogenous hypoglycaemia syndrome, following post-gastric bypass surgery and in patients with insulin receptor mutations [15-18]. This state of the art review will describe first the molecular mechanisms regulating insulin secretion from pancreatic $\beta$-cells, then summarise the clinical presentation of $\mathrm{HH}$ in children and adults and finally focus on the molecular mechanisms of $\mathrm{HH}$ in different age groups and their management.

\section{Physiological Mechanisms Regulating Insulin Secretion from Pancreatic $\beta$-Cells \\ $\nabla$}

The main regulator of insulin secretion is the plasma glucose concentration. Insulin secretion is modified by other nutrients, circulating hormones and the autonomic nervous system, as well as local paracrine and autocrine signals. In pancreatic $\beta$-cells, mitochondrial metabolism translates glucose sensing into signals regulating insulin secretion. Under normal physiological conditions the metabolism of glucose is intricately linked to insulin secretion in pancreatic $\beta$-cells ( $\bullet$ Fig. 1) [19].

Glucose enters the $\beta$-cell and is converted to glucose-6-phosphate by the enzyme glucokinase. Glucokinase plays a unique role in acting as a glucose sensor providing a link between the extracellular glucose concentration and the metabolism of glucose in the $\beta$-cell [20]. When the blood glucose concentration is increased, the activity of glucokinase is also increased hence increasing insulin production from the $\beta$-cell. Similarly as the blood glucose concentration decreases serum insulin becomes undetectable at plasma glucose concentrations below $3 \mathrm{mmol} / \mathrm{l}$ [21,22].

The pancreatic $\beta$-cell possesses a unique signal transduction system, which links the metabolism of the fuel stimulus to initiate insulin secretion, the so called "stimulus-response coupling" [23]. Glucose is the most important fuel involved in the stimulus-response coupling mechanism. This stimulus response-coupling event is controlled by potassium channels $\left(\mathrm{K}_{\mathrm{ATP}}\right)$ located in the pancreatic $\beta$-cell membrane [24]. Each $\mathrm{K}_{\mathrm{ATP}}$ channel consists of a heteromultimeric complex of at least 2 proteins designated SUR1 (ABCC8 gene) and KIR 6.2 (KCNJ11 gene) [25]. The functional integrity of both of these proteins is necessary for potassium channel movement and the genes responsible for them have been localised very closely to each other on the short arm of chromosome 11 (11p14-15.1).

Under normal physiological conditions the $\mathrm{K}_{\text {ATP }}$ channels maintain the electrical potential of the $\beta$-cell membrane. The metabolism of glucose in the $\beta$-cell increases the ratio of ATP/ADP, which has the effect of closing the $\mathrm{K}_{\mathrm{ATP}}$ channels. This in turn causes the opening up of voltage gated calcium channels, which regulate the entry of calcium into the $\beta$-cell. The entry of calcium is thought to be the final stimulus for insulin exocytosis [24]. Thus, the $\mathrm{K}_{\mathrm{ATP}}$ channel functions as an "on/off" switch for triggering insulin secretion.

Although $\mathrm{K}_{\mathrm{ATP}}$ channels have an essential role in linking the metabolism of glucose to the secretion of insulin, there is now evidence that there may well be other mechanisms of insulin secretion, the so-called $\mathrm{K}_{\text {ATP }}$ channel independent pathways of insulin secretion [26-28]. This pathway leads to the augmented insulin release in the presence of raised cytosolic calcium $\left(\mathrm{Ca}^{2+}\right)$ concentrations. Increases in the intracellular $\mathrm{Ca}^{2+}$ concentration in the pancreatic $\beta$-cell cause modest increases in insulin secretion, which can be dramatically increased by modulators of protein kinases and phosphatases [29]. This suggests that steps distal to the elevation of cytosolic $\mathrm{Ca}^{2+}$ are of greater quantitative importance in controlling insulin secretion [29]. It has also been shown that glucose can cause pronounced insulin secretion in $\mathrm{Ca}^{2+}$ depleted islets in the presence of activators of protein kinases A and C [30].

Glucose stimulates insulin gene transcription in pancreatic $\beta$-cells by activation of the homeodomain transcription factor PDX1 (Pancreatic Duodenal Homeodomain transcription factor, PDX1) via a stress-activated pathway involving stress-activated protein kinase 2 [31,32]. PDX1 plays an essential role in linking the cytosolic events to nuclear signalling [33]. Glucose metabolism causes phosphorylation of an inactive 31-kDa PDX1 protein localised exclusively in the cytoplasm resulting in the conver-

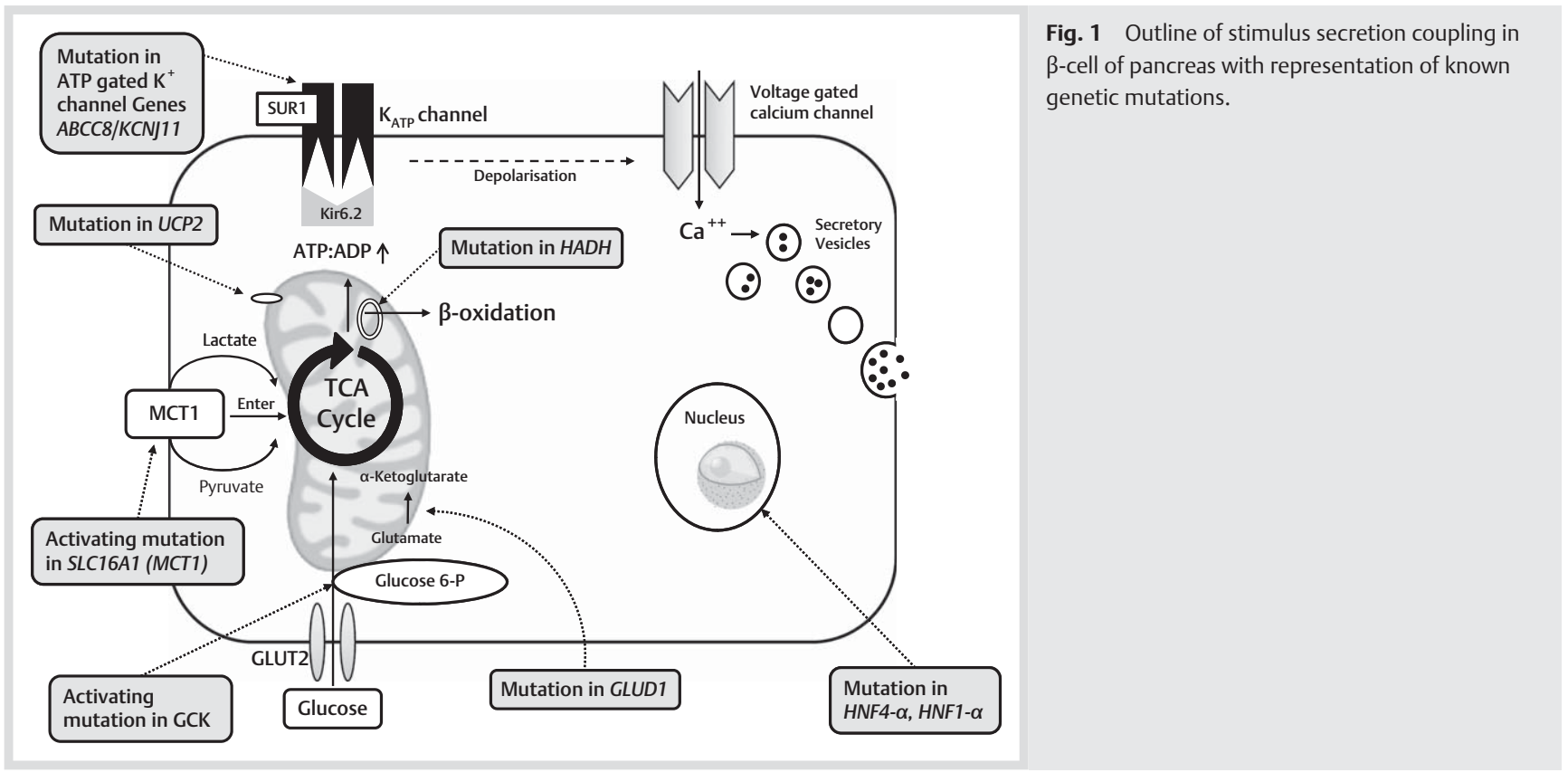


sion of PDX1 to an active 46-kDa form that is predominantly localised in the nucleus $[32,33]$. In addition to binding to the promoter sequences of the insulin gene PDX1 also binds to the coding sequences of other genes, which are specifically expressed in the pancreatic $\beta$-cell such as GLUT2 and glucokinase [34].

\section{Clinical Presentation of $\mathrm{HH}$ \\ $\nabla$}

Most common and severe presentation of HH is during the neonatal period. The presenting symptoms of hypoglycaemia may be very nonspecific (irritability, poor feeding and lethargy) and severe (seizures and coma). Typically these infants are macrosomic and require very high dextrose infusion rate to maintain normoglycaemia. Transient forms of HH are observed in infants born to mothers with diabetes mellitus (insulin dependent or gestational), those who have sustained perinatal asphyxia or those with intrauterine growth restriction (IUGR). In these groups of infants the $\mathrm{HH}$ tends to resolve after few weeks or months.

HH may be the presenting feature in some developmental syndromes such as Beckwith-Wiedemann syndrome (BWS), Soto's syndrome and rare metabolic conditions such as congenital disorder of glycosylation (CDG). The most common syndrome associated with HH is BWS. The vast majority of $\mathrm{HH}$ in BWS is transient and resolves spontaneously. The other clinical features of BWS include prenatal and/or postnatal overgrowth, macroglossia, anterior abdominal wall defects, organomegaly, hemihypertrophy, ear lobe creases, helical pits, and renal tract abnormalities [35].

During infancy and childhood, the presentation of HH may be very subtle and difficult to diagnose. The presenting symptoms before 1 year of age are seizures, episodes of drowsiness or excitability. After 1 year, the symptoms are typical of hypoglycaemia; pallor, faint, tachycardia, sweating and seizures.

Patients with HH due to GLUD1 mutations (HI/HA syndrome) demonstrate 2 characteristic features. First, they show marked sensitivity to dietary protein (and leucine), and symptoms of hypoglycaemia become manifest or aggravated following a protein-rich meal, rather than a fast [36]. Second, they typically show mild to moderate asymptomatic hyperammonaemia. Hypoglycaemia is usually not as severe as that seen in $\mathrm{HH}$ due to $\mathrm{K}_{\text {ATP }}$ channels defects. Children with HI/HA syndrome show good response to therapy with diazoxide and in some cases protein restricted diet. In addition, these children usually are not macrosomic at birth and their hypoglycaemia is often not recognised before several months of age.

HH may be observed postprandially, for example, in the dumping syndrome. The "dumping syndrome" is classically observed in infants following gastro-oesophageal surgery [37]. In exercise induced $\mathrm{HH}$ symptoms of hypoglycaemia occur within the $30 \mathrm{~min}$ following a short period of anaerobic exercise.

Adult onset $\mathrm{HH}$ is usually caused by insulinoma, presenting commonly with recurrent episodes of fasting hypoglycaemia. Rarely, functioning insulinoma can present with hypoglycaemia in the postprandial period [38]. Gastric bypass surgery is increasingly emerging as an important cause of postprandial $\mathrm{HH}$ in adults as a consequence of islet hyperfunction and hypertrophy $[16,17]$. These patients can present with neuroglycopaenia months to years after surgery [16].

\section{Causes of HH (० Table 1)}

$\nabla$

A. $\mathrm{HH}$ due to defects in pancreatic $\beta$-cell $\mathrm{K}_{\text {ATP }}$ channels Given the key role of pancreatic $\beta$-cell $\mathrm{K}_{\mathrm{ATP}}$ channels in regulating insulin secretion it is no surprise that genetic defects in the genes regulating the function of these channels lead to severe forms of $\mathrm{HH}$. Recessive inactivating mutations in $\mathrm{K}_{\mathrm{ATP}}$ channel subunits are the most common cause of $\mathrm{HH}$. As mentioned earlier, $\mathrm{K}_{\text {ATP }}$ channel is a heteromultimeric complex of at least 2 proteins designated SUR1 (ABCC8 gene) and KIR 6.2 (KCNJ11 gene). So far, over 150 mutations have been identified in the $A B C C 8$ and 25 in KCNJ11. These include missense, frame shift, nonsense, insertions/deletions, splice site and regulatory mutations, either present in homozygous or compound heterozygous state. In the Ashkenazi Jewish population, 2 common (F1388del and c.39929G4A) mutations account for $90 \%$ of all cases of congenital $\mathrm{HH}$ [6,39].

The molecular basis of recessive inactivating $A B C C 8$ and $K C N J 11$ mutations involves multiple defects in $\mathrm{K}_{\mathrm{ATP}}$ channel biogenesis and turnover, in channel trafficking from the ER and Golgi apparatus to the plasma membrane and alterations of channels in response to both nucleotide regulation and open state frequency

\begin{tabular}{l}
\hline Table 1 Causes of hyperinsulinaemic hypoglycaemia. \\
Common perinatal risk factors for HH (Likely to be transient) \\
\hline Maternal diabetes mellitus (gestational and insulin dependent) \\
\hline IUGR \\
\hline Perinatal asphyxia \\
\hline Rhesus isoimmunisation \\
Congenital hyperinsulinism (Identified gene mutations) \\
\hline ABCC8 \\
\hline KCNJ11 \\
\hline GLUD1 \\
\hline GCK \\
\hline HADH \\
\hline HNF4A \\
\hline HNF1A \\
\hline SLC16A1 \\
\hline UCP2 \\
\hline Metabolic causes \\
\hline Congenital disorders of glycosylation (CDG), Type 1a/b/d \\
\hline Tyrosinaemia type I. \\
\hline Syndromic causes \\
\hline Beckwith-Wiedemann \\
Kabuki \\
\hline Trisomy 13 \\
\hline Central hypoventilation syndrome \\
Leprechaunism (insulin resistance syndrome) \\
\hline Mosaic Turner \\
\hline Soto \\
\hline Usher \\
\hline Timothy \\
\hline Costello \\
Miscellaneous causes \\
\hline Noninsulinoma pancreatogenous hypoglycaemia \\
Factitious hypoglycaemia \\
\hline Insulinoma \\
Insulin gene receptor mutations \\
\hline Insulin autoimmune syndrome \\
\hline Postprandial HH after post-gastric bypass surgery for obesity \\
\hline Non-islet cells tumor hypoglycemia (NICTH) \\
Dumping syndrome \\
\hline Drug induced [oral antidiabetic drug (sulfonylurea, glinides, biguanides)], \\
beta blockers Antiarrhythmic drugs (cibenzoline, disopyrapide, quinine). \\
\hline
\end{tabular}


[40-43]. There are 2 different classes of these loss-of-function mutations. In class I, all $\mathrm{K}_{\text {ATP }}$ channels are absent from the $\beta$-cell plasma membrane, resulting in no $\mathrm{K}_{\mathrm{ATP}}$ current. The most common class I mutations are those leading to defects in trafficking. In class II mutations, $\mathrm{K}_{\mathrm{ATP}}$ channels are present in the membrane (although less than normal) but show reduced sensitivity to $\mathrm{Mg}$ nucleotide activation or reduced intrinsic channel open probability [19].

The mutation $\mathrm{R} 1437 \mathrm{Q}(23) \mathrm{X}$ in exon 35 of $A B C C 8$ is an example of class I mutation. It causes truncation of the C-terminus of SUR1, which contains the signal sequence necessary for exiting the ER. Thus, the channel protein is retained in the ER and cannot be expressed in the membrane [43]. Point mutations such as G1479R in NBD2 of SUR1 or V187D in the TMD0 of SUR1, which lead to reduced responsiveness to ADP activation in the expressed channels, are examples of class II mutations [19]. Overall, these mutations result in a loss-of-function of $\mathrm{K}_{\text {ATP }}$ channels in the pancreatic $\beta$-cell, leading to constitutive exocytosis of insulin-containing secretory vesicles.

Recessive inactivating mutations in $A B C C 8$ and $K C N J 11$ usually cause severe $\mathrm{HH}$ which in the vast majority of patients is unresponsive to medical treatment with diazoxide. However, some compound heterozygote mutations may be milder and may respond to treatment with diazoxide [44].

Dominant inactivating mutations in $A B C C 8$ and $K C N J 11$ causing $\mathrm{HH}$ have been reported with much milder phenotype than that of patients with recessive inactivating mutations [45]. They usually cause mild medically responsive $\mathrm{HH}$, present later, and do not require a pancreatectomy. However, medically unresponsive dominant $\mathrm{HH}$ has also been reported. The molecular basis of dominant $A B C C 8$ and KCNJ11 mutations involves impaired responsiveness to MgADP and low or nonconducting $\mathrm{K}_{\text {ATP }}$ channels $[46,47]$.

\section{B. HH due to gain of function mutation in the GLUD1 gene}

Mutations in GLUD1 gene [encodes the intramitochondrial enzyme glutamate dehydrogenase (GDH)] cause the second most common congenital form of $\mathrm{HH}$ (HI/HA syndrome) [10]. They are 'activating' mutations, leading to a gain in enzyme function by reducing the sensitivity of GDH to allosteric inhibition by the GTP and ATP [9]. GDH sensitivity to its allosteric activator, leucine is increased, which leads to the increased oxidative deamination of glutamate to $\alpha$-ketoglutarate in the Krebs cycle. $\mathrm{GDH}$ is widely distributed at high levels in the pancreas, liver, brain, kidney, heart and lungs. In pancreatic $\beta$-cells, the resulting increased ATP/ADP ratio consequently activates $\mathrm{K}_{\mathrm{ATP}}$ channels, with subsequent cell depolarisation and insulin release. Increased GDH activity in liver may lead to hyperammonaemia because of excessive ammonia production and impaired urea cycle activity. Recent animal model studies suggest the role of renal ammoniagenesis due to activation of GDH as a source of hyperammonaemia in these patients [48].

The GLUD1 gene mapped to the $10 \mathrm{q} 23.3$ region contains 13 exons encoding a 505 amino acid mature enzyme. Mutations causing HI/HA syndrome have been identified in the GTP allosteric region of the enzyme encoded by exons 11 and 12 of the GLUD1 gene, as well as in the GTP binding site encoded by exons 6 and $7[49,50]$.

The major clinical feature of children with HI/HA syndrome is recurrent episodes of symptomatic $\mathrm{HH}$. These may occur with fasting or can be provoked by protein feeding, as leucine is an allosteric activator of GDH. Some carriers can be asymptomatic, resulting from incomplete expression of enzyme abnormality [51].

Hyperammonaemia, a characteristic biochemical marker of $\mathrm{HI} /$ HA syndrome, is typically mild to moderate (up to 3-5 times the upper limit of normal). It is resistant to detoxification compounds (sodium benzoate, sodium phenylbutyrate, $\mathrm{N}$-carbamylglutamate) or protein-restricted diet [51].

Children with HI/HA syndrome appear to have epilepsy more frequently as compared to other congenital forms of $\mathrm{HH}$ [52-54]. The increased frequency of epilepsy is thought to be either the result of a) hypoglycaemic brain injury due to recurrent hypoglycaemia or b) chronic hyperammonaemia or c) decreased concentrations of glutamine and the neurotransmitter $\gamma$-aminobutyric acid (GABA) in the brain due to raised GDH activity. Overactivity of GDH in the brain may lead to a decrease in glutamate availability for glutamate decarboxylase and GABA synthesis, which results, in turn, in altered GABA concentration [54]. However, measurements of GABA and other neurotransmitters in CSF of these patients have been normal [54]. Finally, mutations in the GTP binding site tend to be more frequently associated with epilepsy than those in the allosteric domain $[53,54]$.

C. HH due to gain of function mutation in the GCK gene Glucokinase (GCK) is a key regulatory enzyme in the pancreatic $\beta$-cells. It plays a crucial role in the regulation of insulin secretion and is referred to as the pancreatic $\beta$-cell sensor [20]. Its unique kinetics of low affinity for glucose (high $\mathrm{Km}$ ) and no inhibition by its end product glucose-6-phosphate helps in modulation of its activity in relation to the concentration of glucose over a range of physiological glucose concentrations $(4-15 \mathrm{mmol} / \mathrm{l})$. Hence pancreatic $\beta$-cells are able to increase their rate of glucose metabolism in response to a rise in the extracellular glucose concentration.

Activating (or gain of function) mutations in GCK increase the affinity of GCK for glucose and alter the threshold for glucose stimulated insulin secretion [55]. Thus insulin continues to be produced at lower blood glucose concentrations. All reported activated mutations cluster in the allosteric activator site of the enzyme. There is no evidence of increased gene expression as a likely cause of $\mathrm{HH}$.

GCK mutations can lead to a variable phenotype, ranging from asymptomatic hypoglycaemia to medically unresponsive $\mathrm{HH}$, with majority causing mild diazoxide responsive $\mathrm{HH}$ [56-59]. In a large study, activating GCK mutations accounted for $~ 7 \%$ of medically responsive $\mathrm{HH}$ [60].

\section{Transcription factors and $\mathrm{HH}$}

The hepatocyte nuclear factor $4 \alpha$ (HNF- $4 \alpha$ ), encoded by HNF4A, is a member of the nuclear receptor (NR) family of transcription factors. The HNF4A gene is highly expressed in the liver, kidney, gut, and pancreatic islets and is thought to play an important role in the development and function of these organs [61]. Other transcription factors important for the development of the pancreas include HNF-1 $\alpha$ and HNF-1 $\beta$ [62]. These along with HNF- $4 \alpha$ are thought to play a crucial role in expression of several genes involved in glucose stimulated insulin secretion [63].

Heterozygous mutations in HNF4A lead to a dominantly inherited condition with a dual phenotype of MODY1 and HH [64,65]. Clinically HNF4A mutation is characterised by an early neonatal presentation of $\mathrm{HH}$ and macrosomia. The severity may range from mild transient hypoglycaemia not needing medication to 
persistent $\mathrm{HH}$ requiring treatment with diazoxide for up to 8 years [63]. In all reported cases, the $\mathrm{HH}$ improved with age and responded to diazoxide. A variable penetrance is often observed within families, demonstrated by absence of neonatal $\mathrm{HH}$ in some HNF4A mutation carriers. A family history of diabetes is a useful indicator of an HNF4A gene mutation, however its absence should not preclude HNF4A sequencing in patients with diazoxide responsive $\mathrm{HH}$ [63]. The reason for the differences in clinical presentations is not currently understood; though, it is likely that other genetic and environmental factors may influence the severity of the disease. The HNF4A mutation phenotype may extend beyond $\beta$-cells of pancreas and include liver glycogenosis and renal Fanconi tubulopathy [66].

The exact mechanism behind HH in HNF4A mutations is unclear but may involve reduced expression of the potassium channel subunit Kir6.2, as was found in conditional knockout of HNF4A [67]. The other possible mechanism is HNF- $4 \alpha$ deficiency leads to lower levels of PPAR $\alpha$ (peroxisomal proliferator-activated receptor alpha), which is important for insulin regulation [68].

A recent report described 2 cases with diazoxide responsive $\mathrm{HH}$ associated with mutations in HNF1A [66]. The phenotype described is very similar to HNF4A mutations - macrosomia, early neonatal presentation and diazoxide responsiveness.

\section{$\mathrm{E}$. $\mathrm{HH}$ and defects in the mitochondrial oxidation enzyme short chain 3 hydroxyacyl-coenzyme $A$ dehydrogenase (SCHAD)}

Short chain L-3-hydroxyacyl-CoA dehydrogenase (SCHAD) catalyses the penultimate step in fatty acid $\beta$-oxidation in the mitochondria. It is encoded by $H A D H$, which is highly expressed in the pancreatic $\beta$-cells. Short chain 3-hydroxyacyl-CoA dehydrogenase (SCHAD) deficiency is a recently described disorder of mitochondrial fatty acid $\beta$-oxidation $[9,69,70]$. Unlike other inherited defects of fatty acid $\beta$-oxidation, the main clinical feature of this metabolic disease is $\mathrm{HH}$.

A number of studies have demonstrated that $H A D H$ has a pivotal role in regulating insulin secretion $[71,72]$. Recently, the mechanism behind unregulated insulin secretion in SCHAD deficiency is becoming clear. These patients were noticed to be severely protein sensitive, suggesting an amino acid triggered unknown pathway of insulin release [73]. Subsequently $H A D H-/-$ knockout mice studies demonstrated protein-protein interactions between HADH and glutamate dehydrogenase (GDH) [74]. Similar interactions have been reported in human control lymphoblast, which are lost in patients with $H A D H$ mutations [75]. Studies on isolated islets showed an increase in the affinity of GDH for its substrate $\alpha$-ketoglutarate. It is therefore likely that $H A D H$ mutations cause $\mathrm{HH}$ by activation of GDH via loss of inhibitory regulation of GDH by HADH.

Metabolic profile in affected individuals may reveal a raised plasma hydroxylbutyrylcarnitine and urinary 3-hydroxyglutarate levels. However, the reason why not all patients show abnormal organic acid profiles or defects in acylcarnitine metabolism is unclear. Most cases reported to date are from consanguineous families [76]. Hence sequencing of $\mathrm{HADH}$ is recommended in patients with diazoxide responsive congenital $\mathrm{HH}$ who come from consanguineous families and do not have an identifiable mutation in the $A B C C 8 / K C N J 11$ genes.

\section{F. Exercise-induced hyperinsulinism (EIHI)}

Exercise-induced hyperinsulinism (EIHI) is an autosomal dominant disorder in which strenuous physical exercise causes inap- propriate insulin secretion in affected individuals, leading to hypoglycaemia. Heterozygous gain-of-function mutations in the solute carrier family 16 , member 1 (SLC16A1) that encodes monocarboxylate transporter 1 (MCT1; required for transmembrane transport of pyruvate and lactate) causes exercise induced hyperinsulinism [77-79].

In normal individuals, expression of the pyruvate transporter (MCT1) is specifically silenced in pancreatic $\beta$-cells, despite nearly universal expression across other tissues [79]. Affected patients have symptoms due to activating mutations in the SLC16A1 promoter in $\beta$-cells. Increased expression of MCT1 thus renders the plasma membrane permeable to lactate and pyruvate, allowing the latter to inappropriately stimulate insulin secretion [79]. Affected patients do not normally experience fasting hypoglycaemia. During exercise pyruvate is generated along with lactate by muscle, thereby stimulating inappropriate insulin secretion from the pancreatic $\beta$-cell despite low blood glucose levels. The mechanism highlights the importance of MCT1 absence from these cells for the normal control of insulin secretion. Although the $\mathrm{HH}$ is usually quite severe in these patients, specific treatment is not usually needed as hypoglycaemic episodes may be prevented by avoiding strenuous exercise.

\section{G. Insulinoma}

An insulinoma is the commonest cause of endogenous $\mathrm{HH}$ in adults. They are insulin secreting tumours of pancreatic origin, with an incidence of 1-4 per million [80]. Majority (90\%) of them are benign, solitary, intrapancreatic and $<2 \mathrm{~cm}$ in diameter. Classically, symptoms become evident in the fasting state or following exercise. However, it is now known that insulinoma can also present with postprandial symptoms [81]. Diagnosis was previously based on findings of abnormal serum levels of insulin, C-peptide, and more recently, proinsulin at the time of fasting hypoglycaemia [21].

\section{Postprandial Hyperinsulinaemic Hypoglycaemia (PPHH)}

PPHH refers to hypoglycaemia within a few hours of meal ingestion secondary to inappropriate insulin secretion in response to a meal.

\section{A. Dumping syndrome}

Dumping syndrome seen in infants after Nissen's fundoplication is a classic example of PPHH [82]. Precipitous emptying of hyperosmolar carbohydrate-containing solutions into the small bowel results in rapid glucose absorption, hyperglycaemia and reactive hypoglycaemia. These children also tend to have abnormally exaggerated secretion of Glucagon Like Peptide-1 (GLP-1), which may contribute to the exaggerated insulin surge and resultant hypoglycaemia [83].

The cause of hypoglycaemia in these circumstances is usually investigated by oral glucose tolerance test (OGTT) or by a mixedmeal provocation test. Physiological dip in blood glucose level seen in OGTT might lead to misdiagnosis. However, corresponding biochemical evidence of endogenous hyperinsulinaemia and symptoms of neuroglycopaenia during a hypoglycaemic episode would help distinguish between pathological PPHH and reactive hypoglycaemia. A decrease of $>6 \mathrm{mmol} / \mathrm{l}$ between peak and nadir blood glucose during OGTT has been used as a diagnostic criterion for dumping syndrome [84]. 


\section{B. Insulin autoimmune syndrome}

Insulin autoimmune syndrome or Hirata disease is a rare condition characterised by $\mathrm{HH}$ associated with high titre of antibodies to endogenous insulin, in the absence of pathologic abnormalities of pancreatic islets and prior exposure to exogenous insulin [85]. The disease is extremely uncommon in Western countries. Insulin autoimmune syndrome affects men and women equally and is seen more frequently in patients older than 40 years of age.

The binding kinetics of endogenous insulin by the antibodies are thought to lead to physiologically inappropriate levels of bioavailable insulin, causing either hyper- or hypoglycaemia. In this syndrome, the insulin levels are markedly elevated, usually above $100 \mathrm{mU} / \mathrm{l}$ [86]. After a meal or glucose load, these patients often demonstrate initial hyperglycaemia, followed by hypoglycaemia a few hours later. The hyperglycaemia is caused by the anti-insulin antibodies that bind the insulin secreted in response to rising blood glucose levels after a meal. This binding reduces the bioavailability of the secreted insulin to the receptors in the liver and peripheral tissues, resulting in hyperglycaemia and further insulin secretion. As the blood glucose concentrations begin to decrease and insulin secretion declines, the insulin bound to the antibodies is released, resulting in inappropriately high free insulin concentrations for the blood glucose, causing hypoglycaemia [86].

\section{PPHH in patients with insulin-receptor mutations}

Postprandial $\mathrm{HH}$ has been described in patients who carried a heterozygote mutation (Arg1174GIn) in the insulin-receptor gene [18]. Hyperinsulinism seems to be associated with decreased degradation rather than increased secretion of insulin, as evidenced by increased fasting levels of serum insulin despite normal levels of serum C-peptide and reduced clearance of exogenous insulin during clamp studies [18].

\section{PPHH after gastric bypass surgery}

A consequence of the obesity epidemic is the increasing use of gastric bypass surgery for patients with severe, medically complicated obesity, which has led to a number of reports of postprandial HH $[16,17]$. In a review of Swedish Bariatric Surgery registry, the incidence of hospitalisation for hypoglycaemia in post gastric bypass patients was reported as less than $1 \%$ [87].

A number of different explanations have been suggested to explain hypoglycaemia post gastric bypass surgery. This can either be a manifestation of dumping syndrome or improved insulin sensitivity following weight loss unmasking an underlying hyperinsulinaemia syndrome. The hypoglycaemia could also be due to an effect on "enteroinsular axis" induced by the diversion of nutrients into the small intestine.

The principal reason seems to be enhanced postprandial insulin secretion, thought due primarily to increased secretion of GIP (glucose-dependent insulinotropic polypeptide (GIP) and, especially GLP-1. GLP-1 levels are now well documented to be increased 2- to 5-fold after gastric bypass [88-90]. The elevations of incretins tend to be seen early, even as early as 2 days after gastric bypass, and levels may decline as substantial weight loss and normalisation of insulin sensitivity occurs [89]. In patients with PPHH, elevated levels of GIP and GLP-1 persist for years after surgery $[88,91]$.

Increased postprandial insulin secretion by incretins is mediated by islet cell hypertrophy and hyperplasia, first reported in 5 patients who developed postprandial $\mathrm{HH}$ after gastric bypass surgery [16]. Both GIP and GLP-1 have been implicated in increasing pancreatic $\beta$-cell mass in rodent models $[92,93]$. GLP-1 regulates islet growth though inducing the expression of the transcription factor pancreatic-duodenum homeobox-1 (PDX-1) [92].

Overexpression of insulin-like growth factor 2 (IGF2), and insulin-like growth factor 1 receptor alpha (IGF1R $\alpha$ ) have been noticed in pancreatic tissue removed from patients with persistent PPHH after gastric bypass surgery as compared to controls [94]. These findings are suggestive of the role of growth factors in islet hyperfunction seen in post gastric bypass patients.

\section{E. Noninsulinoma pancreatogenous hypoglycaemia syndrome}

Noninsulinoma pancreatogenous hypoglycaemia syndrome (NIPHS) is characterised by postprandial neuroglycopaenia [15]. Investigations reveal negative prolonged fasting tests and negative perioperative localisation studies for insulinoma. However in some patients the selective arterial calcium stimulation tests is positive with the histology of the resected pancreas showing nesidioblastosis [12]. The underlying genetic basis of NIPHS is not known.

These patients are negative for $A B C C 8 / K C N J 11$ mutations and show islet hypertrophy histologically (as observed in diffuse congenital $\mathrm{HH}$ ). The positive responses to selective arterial calcium stimulation in some patients with NIPHS, despite negative radiological localizing studies, establish that this technique should be performed in all adults with HH of unknown aetiology. Immunohistological studies of the resected pancreatic tissues have failed to show increased rate of proliferation of $\beta$-cells, or abnormal synthesis and/or processing of either proinsulin or amylin. Neither there has been any evidence of overexpression of pancreatic differentiation factors, PDX-1 and Nkx-6.1, as well as the calcium sensing receptor (CaSR) [95].

These patients usually require partial pancreatectomy to relieve further neuroglycopaenic attacks. However in some patients, diazoxide does seem to attenuate the insulin response to meals [95].

\section{Molecular Basis of Diffuse and Focal HH $\nabla$}

Despite identical clinical presentation, at least 2 (possibly more) well described histological types are associated with $\mathrm{HH}$ : a focal form and a diffuse form [13]. In diffuse form, all of the islets of Langerhans throughout the pancreas are enlarged and contain distinctly hypertrophied insulin producing cells. Focal form is characterised by nodular hyperplasia of islet-like cell clusters, including ductuloinsular complexes and giant $\beta$-cell nuclei surrounded by a histologically and functionally normal pancreatic tissue.

These 2 subtypes have different underlying genetic mechanisms. The most common causes of diffuse $\mathrm{HH}$ are recessive and dominant mutations in $A B C C 8$ and $K C N J 11$. The focal form has a unique genetic aetiology and involves 2 independent events the inheritance of a paternal mutation in ABCC8 or KCNJ11, and somatic loss of the maternal $11 \mathrm{p}$ allele (11p15.1 to $11 \mathrm{p} 15.5$ ) involving the $A B C C 8$ and $K C N J 11$ region within the focal lesion [96]. The maternal $11 \mathrm{p}$ loss leads to paternal uniparental disomy unmasking the paternally inherited $\mathrm{K}_{\mathrm{ATP}}$ channel mutation, and leading to altered expression of a number of imprinted genes in this region, including the maternally expressed tumour suppres- 
Table 2 Biochemical profile diagnostic of $\mathrm{HH}$.

\begin{tabular}{|c|c|c|}
\hline & $\begin{array}{l}\text { Hormone/intermediary } \\
\text { metabolite }\end{array}$ & Result in $\mathrm{HH}$ \\
\hline \multirow{11}{*}{$\begin{array}{l}\text { Blood } \\
\text { Samples }\end{array}$} & Insulin & Detectable or elevated \\
\hline & C-Peptide & Detectable or elevated \\
\hline & Free fatty acids & Inappropriately low \\
\hline & $\beta$-Hydroxybutyrate & Inappropriately low \\
\hline & Acetoacetate & Inappropriately low \\
\hline & Lactic acid & Normal \\
\hline & Hydroxybutyrylcarnitine & Elevated in HADH deficiency \\
\hline & Brain chain amino acids & Low \\
\hline & Ammonia & Elevated in $\mathrm{HI} / \mathrm{HA}$ syndrome \\
\hline & Cortisol & Elevated due to hypoglycemia \\
\hline & IGFBP-1 & Low \\
\hline \multirow{2}{*}{$\begin{array}{l}\text { Urine } \\
\text { Samples }\end{array}$} & Ketones & Negative \\
\hline & 3-hydroxyglutarate & Elevated in $\mathrm{HADH}$ deficiency \\
\hline \multicolumn{3}{|c|}{ Blood glucose $<3 \mathrm{mmol} / \mathrm{l}$ on glucose infusion rate of $>8 \mathrm{mg} / \mathrm{kg} / \mathrm{min}$} \\
\hline $\begin{array}{l}\text { HI/HA sync } \\
\text { hydroxyac) }\end{array}$ & $\begin{array}{l}\text { me: Hyperinsulinism hyperam } \\
\text { coenzyme A dehydrogenase) }\end{array}$ & onaemia; SCHAD: Short chain L- \\
\hline
\end{tabular}

sor genes $\mathrm{H} 19$ and $C D K N 1 C$, and the paternally expressed growth factor IGF2 [97]. These events form the basis of unregulated insulin secretion and focal increased proliferation of $\beta$-cells evolving into a focal adenomatous hyperplasia. The focal disease is mostly sporadic in origin; however, a familial case has been reported in literature [98].

\section{Approach to Diagnosis and Investigations (0 Table 2) \\ $\nabla$}

The management approach involves establishing a clear diagnosis of $\mathrm{HH}$, undertaking appropriate genetic analysis as guided by clinical and biochemical findings, evaluating the potential for controlling hypoglycaemia by medical therapy and determining whether surgery will be required.

The primary goal is to prevent neurologic symptoms and sequelae by early identification and maintenance of normoglycaemia (blood glucose levels $3.5-6 \mathrm{mmol} / \mathrm{l}$ ) [1]. The diagnosis of $\mathrm{HH}$ is based on clinical presentation and detection of characteristic biochemical profile of hypoketonaemic, hypofattyacidaemic hypoglycaemia arising from the anabolic effects of excessive insulin action at the time of hypoglycaemia. Certain clinical clues for diagnosis of HH includes macrosomia or severe IUGR, and high glucose requirement $(>8 \mathrm{mg} / \mathrm{kg}$ min, normal range $4-6 \mathrm{mg} / \mathrm{kg} \mathrm{min}$ ) to maintain normoglycaemia.

Characteristic metabolic profile can either be identified during spontaneous hypoglycaemia or hypoglycaemia induced by provocation tests (controlled fast/exercise/protein ingestion). However, provocation test should only be done within a controlled environment with appropriate monitoring as it can be potentially life-threatening. Laboratory findings at time of hypoglycaemia would unveil inappropriately elevated insulin and inappropriately low beta-hydroxybutyrate and free fatty acids. Plasma insulin levels may not be dramatically elevated. Under normal physiological conditions, insulin production is switched off during hypoglycaemic state. As insulin release is pulsatile and has a short half-life, measurement of C-peptide (which has a longer half-life and reflects the endogenous insulin production) can prove to be more helpful when the diagnosis is in doubt.

Additional supportive evidence can be provided by a positive glycaemic response to intramuscular/intravenous glucagon at the time of hypoglycaemia (a clear increment in blood glucose of $>1.5 \mathrm{mmol} / \mathrm{l}$ despite severe hypoglycaemia), a positive glycaemic response to octreotide and a decreased serum levels of insulin-like growth factor-binding protein 1 (IGFBP-1) (as insulin suppresses the transcription of IGFBP-1 gene) $[2,99,100]$. A low serum cortisol and/or growth hormone levels at the time of hypoglycaemia is not diagnostic of cortisol or growth hormone deficiency [3]. Appropriate stimulation tests are required to confirm cortisol or growth hormone deficiency.

In the persistent rare forms of congenital $\mathrm{HH}$, certain specific diagnostic findings can suggest likely underlying genetic diagnosis. Elevated serum ammonia and $\mathrm{HH}$ imply $\mathrm{HI} / \mathrm{HA}$ syndrome (GDH-HH) [101]. However, normal ammonia concentrations do not necessarily exclude GDH-HH. In these patients with "activating" GLUD1 mutations, hypoglycaemia may occur after ingestion of leucine- or protein-rich meal and can be provoked by performing a protein/leucine provocation test $[102,103]$.

Abnormal plasma acylcarnitine profile (elevated 3-hydroxtbutyrylcarnitine) and urine organic acids (3-hydroxyglutarate in urine) characterise HADH-HH [9]. If $\mathrm{HH}$ is related to exercise, consider performing an exercise provocation test or a pyruvate load test [77]. An exercise test with submaximal to maximal exercise over $10 \mathrm{~min}$ is diagnostic.

In patients with mutations in HNF4A and UCP2, there are no specific laboratory findings. HNF4A mutations are associated with a considerable increase in birth weight, macrosomia and family history of MODY $[64,65]$. However, prenatal hyperinsulinism due to other genetic causes may also increase the birth weight. Family history of MODY and postprandial HH may denote GCK-HH.

In adults with $\mathrm{HH}$, a supervised 72-h fast has been the classic diagnostic test as insulinoma, the commonest cause of $\mathrm{HH}$ in adults, would be detected in 99\% cases [104]. Critical diagnostic findings are plasma insulin concentrations of at least $3 \mu \mathrm{U} / \mathrm{ml}$ (18 pmol/l), plasma C-peptide concentrations of at least $0.6 \mathrm{ng} /$ $\mathrm{ml}(0.2 \mathrm{nmol} / \mathrm{l})$, and plasma proinsulin concentrations of at least $5.0 \mathrm{pmol} / \mathrm{l}$ when the fasting plasma glucose concentrations are below $55 \mathrm{mg} / \mathrm{dl}$ (3.0 mmol/l) [21]. Measurement of sulfonylureas in plasma and urine is recommended in all patients to rule out factitious hypoglycaemia due to administration of sulfonylureas. Measurement of insulin antibodies is essential to rule out insulin autoimmune syndrome.

The patient with a history suggestive of postprandial hypoglycaemia should undergo a mixed-meal tolerance test (MMTT) [21]. A MMTT seems to be superior to an oral glucose tolerance for the evaluation of suspected postprandial hypoglycaemia. Postprandial $\mathrm{HH}$, negative 72 -h fasting studies, and positive selective arterial calcium stimulation test characterise noninsulinoma pancreatogenous hypoglycaemia syndrome [NIPHS] [15].

\section{Therapies for Different Forms of HH Congenital HH (0 Fig. 2) \\ $\nabla$}

\section{Medical management}

The goal of treatment in patients with $\mathrm{HH}$ is to maintain normoglycaemia (blood glucose levels between $3.5-6 \mathrm{mmol} / \mathrm{l}$ ). Intravenous dextrose infusion of up to $15-25 \mathrm{mg} / \mathrm{kg} / \mathrm{min}$ through an established central venous access may be required to maintain normoglycaemia in neonates with severe forms of HH. This should be supported with enteral feeding to maintain orality. It 


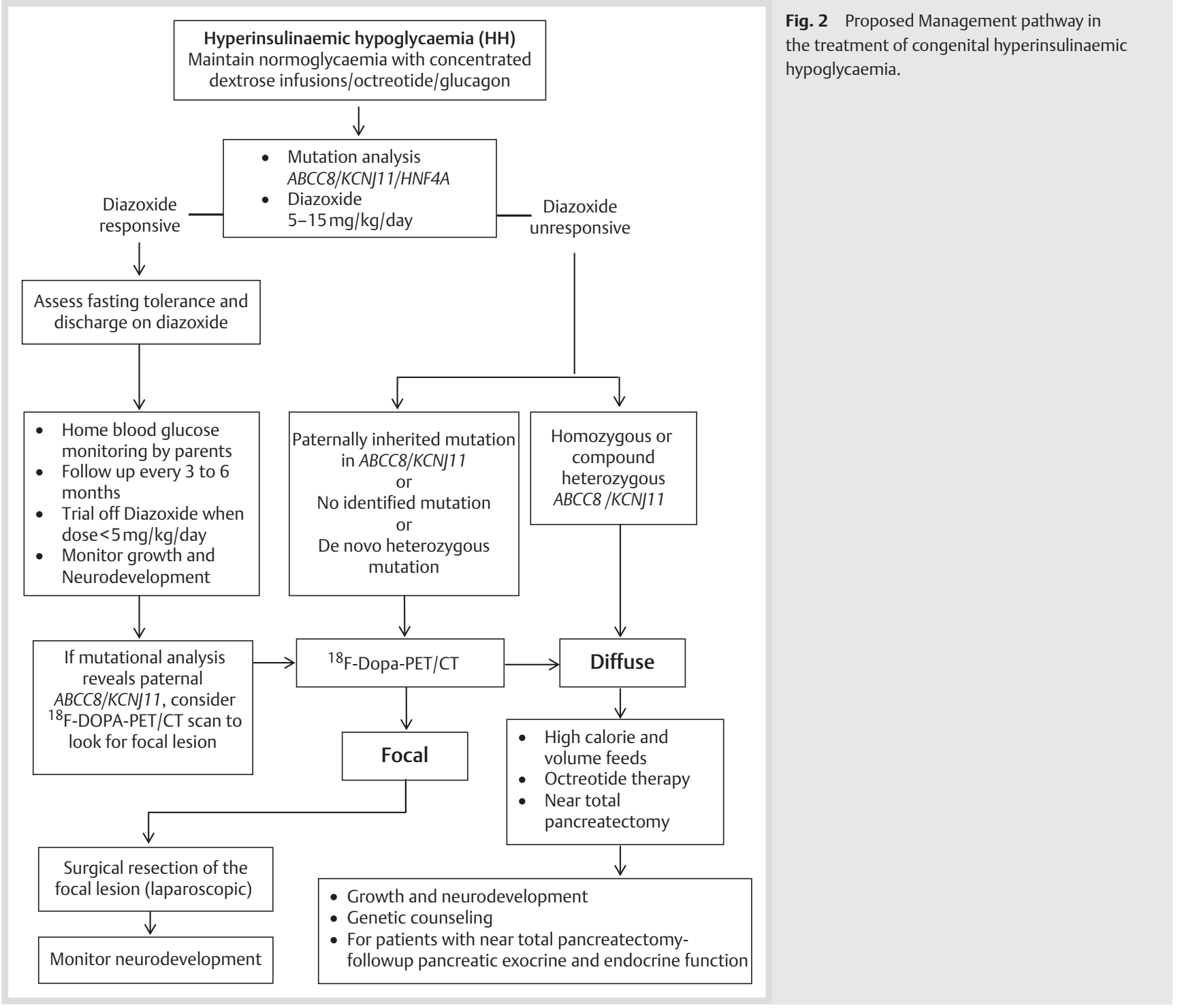

is important to note that orality is often affected possibly due to disturbed feeding pattern and gastro-oesophageal reflux, often inducing feeding refusal behaviour. Frequent monitoring of blood glucose levels is required.

Once the diagnosis of $\mathrm{HH}$ has been confirmed, medical therapy with diazoxide should be initiated, and within the first week of diagnosis, the response to diazoxide would give an indication for the need of further evaluation and surgical intervention.

In all new-borns and infants diagnosed with $\mathrm{HH}$, diazoxide $\left(\mathrm{K}_{\mathrm{ATP}}\right.$ channel opener) is the first-line medical therapy. Diazoxide is administered orally at a starting dose of $5 \mathrm{mg} / \mathrm{kg} /$ day in 3 divided doses. The dose can be increased by $5 \mathrm{mg} / \mathrm{kg} /$ day every $48 \mathrm{~h}$ to an effective and tolerated dose (the maximal dose rate is $15 \mathrm{mg} /$ $\mathrm{kg} / \mathrm{d})[105,106]$. The responsiveness to diazoxide is determined by a) appropriate fasting tolerance for age; b) feed volume and frequency normal for age; c) normal blood glucose levels at the end of the fast.

The use of diazoxide is often limited by its side effects. The most common side effects of diazoxide are hypertrichosis and fluid retention (especially in the newborn), followed by hyperuricaemia, tachycardia, leukopenia, and feeding problems. In newborns, the drug is given in conjunction with the thiazide diuretic chlorothiazide (5-10 $\mathrm{mg} / \mathrm{kg}$ per day in 2 divided doses), which reduces water retention. If the dose of diazoxide falls below $5 \mathrm{mg} / \mathrm{kg} /$ day, a trial off diazoxide should be considered under medical observation in the hospital setting. In those with less severe $\mathrm{HH}$ (HH associated with perinatal stress or IUGR), it may be preferable to start at a lower dose $(2-3 \mathrm{mg} / \mathrm{kg} /$ day $)$ of diazoxide.

Diazoxide is an agonist of the $\mathrm{K}_{\mathrm{ATP}}$ channel and a dose range of (5-15 mg/kg/day) is usually effective in all forms of congenital $\mathrm{HH}$, except those caused by autosomal recessive mutations in the $A B C C 8$ and $K C N J 11$ genes [1]. A functional $\mathrm{K}_{\text {ATP }}$ channel is required for diazoxide to exert an effect. Hence patients with focal or diffuse $\mathrm{K}_{\mathrm{ATP}} \mathrm{HH}$ do not respond to therapy with diazoxide. Patients with GDH-HH, SCHAD-HH, HNF4A and transient $\mathrm{HH}$ typically respond well to diazoxide. Patients with GCK-HH have a variable response to diazoxide and some may require surgery [56].

Patients unresponsive to maximum doses of diazoxide need urgent genetic analysis to identify those who should undergo ${ }^{18} \mathrm{~F}$-DOPA-PET/CT in search of a focal lesion. Those with a paternally inherited $A B C C 8 / K C N J 11$ mutation are likely to have a focal lesion. While these investigations are carried out, normoglycaemia should be achieved with second-line medications.

Octreotide is the second line of medical therapy for infants with diazoxide unresponsive congenital HH. Octreotide inhibits insu- 
lin secretion by activation of somatostatin receptor- 2 and -5 and inhibition of calcium mobilisation in $\beta$-cells [107]. Octreotide is administered subcutaneously every $6-8 \mathrm{~h}$, beginning at a low dose $(5 \mu \mathrm{g} / \mathrm{kg} / \mathrm{day})$ and titrating up to a maximum of $30 \mu \mathrm{g} / \mathrm{kg} /$ day. Necrotizing enterocolitis is a rare but potentially life-threatening adverse effect of octreotide and therefore, it must be used with caution in neonates [108]. In most patients, there is transient hyperglycaemic response to the initial doses of octreotide. However desensitisation can occur after 2-3 doses, requiring increasing doses (tachyphylaxis) which in some patients makes this drug unsuitable for long-term use. There are reports suggesting that continuous subcutaneous octreotide infusion can overcome tachyphylaxis and lead to reduction in the dosage required as compared to when given by multiple daily injections $[109,110]$.

Treatment with long acting preparations of octreotide has been reported to be successful in older children and needs more research to prove efficacy in younger group of patients $[111,112]$. In combination with frequent feeding, it may be a long-term treatment option either alone or in conjunction with diazoxide [112]. In diazoxide unresponsive patients, glucagon can be given along with octreotide, as a continuous intravenous infusion as a rescue therapy to help maintain normoglycaemia [113].

GLP-1 receptor may be a new therapeutic target in future for children with $\mathrm{K}_{\text {ATP }} \mathrm{HH}$. In a mouse model of $\mathrm{K}_{\text {ATP }} \mathrm{HH}$ (SUR-1 - /-), treatment with exendin-(9-39) (GLP-1 receptor antagonist) had been shown to result in improved fasting blood glucose levels [97]. The authors' findings suggested CAMP may have a role in $\mathrm{K}_{\text {ATP }} \mathrm{HH}$ as cAMP content in SUR-1 - /- was reduced by exendin-(9-39) both basally and when stimulated by the amino acids [114]. More recently, in a randomised, open-labelled, 2-period crossover pilot clinical study involving 9 human subjects with $\mathrm{K}_{\text {ATP }} \mathrm{HH}$, it was shown that significantly higher nadir blood glucose levels were observed with exendin-(9-39) as compared to placebo. These findings propose that GLP- 1 and its receptor may play a role in the regulation of fasting glycaemia in $\mathrm{K}_{\mathrm{ATP}} \mathrm{HH}$ [115].

\section{Surgical management}

The indications for surgery in $\mathrm{HH}$ patients include medically unresponsive diffuse disease and confirmed focal disease on ${ }^{18} \mathrm{~F}$-DOPA-PET/CT scan. Despite the huge advances in diagnosing and accurately localising focal lesions preoperatively with novel imaging techniques such as ${ }^{18} \mathrm{~F}$-DOPA-PET/CT there is still a potential for ambiguity. Therefore, it is very important to have an experienced surgeon, endocrinologist, as well as pathologists trained in evaluating intraoperative frozen sections to confirm the focal lesions, which aid in guiding the extent of the surgery. Infants with diffuse disease require a near-total pancreatectomy (95-98\% removal) to control the $\mathrm{HH}$. They might require additional therapy post-operatively with diazoxide, octreotide, and/ or frequent feedings to maintain normoglycaemia. Laparoscopic pancreatectomy is a new approach to the diagnosis and management of patients with congenital $\mathrm{HH}$ associated with less operative trauma and faster recovery than traditional laparotomy $[116,117]$.

\section{Histology}

Focal lesions are characterised by nodular hyperplasia of isletlike cell clusters with ductuloinsular complexes and scattered giant $\beta$-cell nuclei with surrounding normal tissue [118-120]. Focal lesions are usually less than $10 \mathrm{~mm}$ in diameter. Rarely, large focal lesions that occupy virtually the entire pancreas have been reported and ${ }^{18} \mathrm{~F}$-DOPA-PET/ CT scans may be difficult to interpret in these patients with giant lesions [121].

With the aid of the ${ }^{18} \mathrm{~F}$-DOPA-PET/CT scan, molecular genetics, experienced pathologists, and an experienced surgeon, complete resolution of $\mathrm{HH}$ can be achieved with a limited pancreatectomy in focal disease [122-124]. Detailed morphology of the islets of Langerhans in diffuse $\mathrm{HH}$ reveals large $\beta$-cells with abnormally large nuclei [125] throughout the pancreas. Subtotal and even near-total pancreatectomy may be insufficient to relieve the hypoglycaemia in these patients with diffuse disease. Recently, a new atypical histological form of $\mathrm{HH}$ was characterised by morphological mosaicism [126]. In this histological form 2 types of islets coexist: large islets with cytoplasm rich $\beta$-cells and occasional enlarged nuclei and shrunken islets with $\beta$-cells exhibiting little cytoplasm and small nuclei [122]. Large islets were mostly confined to few lobules. This form has the potential of cure with partial pancreatectomy and hence pathologists are recommended to recognise this mosaicism on intraoperative frozen sections [122]. In vitro studies on islets isolated from patients with this atypical form showed elevated insulin secretion at $1 \mathrm{mmol} / \mathrm{l}$ glucose and immunohistochemistry revealed undue presence of low- $\mathrm{K}_{\mathrm{m}}$ hexokinase-I in $\beta$-cells of hyperfunctional islets [127]. This represents a novel cause of focal congenital $\mathrm{HH}$.

\section{Follow-up}

Focal forms of congenital $\mathrm{HH}$ are completely cured after the resection of focal lesion and do not require as intensive followup as diffuse HH. After initial successful management of diffuse $\mathrm{HH}$, these children should be closely followed up with regular 24-h glucose profile and controlled fast for ensuring optimal glycaemic control. Parents/carers should also perform rigorous blood glucose monitoring at home. Most children will become milder as they grow older. Few children will need adjustment in the medication doses with increase in weight. Over the longterm period, specific subgroups of patients such as those managed with near-total pancreatectomy are at higher risk of developing diabetes mellitus [128].

\section{Role of genetics in management of congenital severe $\mathrm{HH}$}

In diazoxide unresponsive infants, mutation analysis of the $\mathrm{K}_{\mathrm{ATP}}$ channel genes ( $A B C C 8$ and KCNJ11) can provide helpful information for differentiating focal from diffuse $\mathrm{HH}$. In patients with homozygous or compound heterozygous mutations in KATP channel genes, the disease will be diffuse, whereas in patients carrying paternally inherited heterozygous mutations, focal disease is likely and further investigations with ${ }^{18} \mathrm{~F}$-DOPA-PET/CT are warranted $[96,129]$. However, in a significant proportion, heterozygous $\mathrm{K}_{\text {ATP }}$ mutations may be dominant-acting and lead to diffuse disease. Additionally, approximately half of $\mathrm{HH}$ patients do not have mutations in known genes with a role in insulin secretion $[11,12]$.

The interpretation of mutation results is complicated with novel variants, with whom it may be difficult to determine whether the defect is expressed recessively or dominantly. Finding a paternally derived $A B C C 8 / K C N J 11$ mutation is consistent with but does not guarantee focal $\mathrm{HH}$ [11]. A patient with a paternally-derived mutation may have a post-zygotic disease-causing mutation on the maternal allele that is not expressed in peripheral blood cells, resulting in diffuse HI. Finding a recessive, dis- 
ease-causing $\mathrm{K}_{\mathrm{ATP}}$ channel mutation transmitted from the mother excludes the possibility of a focal lesion. Furthermore, as only coding regions and conserved splice sites are sequenced in Sanger sequencing, patients with no mutations identified in known genes regulating insulin secretion may have deep intronic mutations, which get overlooked with Sanger sequencing [130].

\section{Role of the ${ }^{18} \mathrm{~F}$-DOPA-PET/CT in management of congenital $\mathrm{HH}$}

In medically unresponsive $\mathrm{HH}$ with paternally inherited, de novo or no identified mutation in $\mathrm{K}_{\text {ATP }}$ channel genes, the 2 histological subtypes, focal and diffuse, needs to be differentiated before planning surgery, as the surgical approaches for them are completely different. The diagnosis of diffuse disease is definitive in patients homozygous or compound heterozygous for $\mathrm{K}_{\mathrm{ATP}}$ channel genes. ${ }^{18} \mathrm{~F}-\mathrm{DOPA}-\mathrm{PET} / \mathrm{CT}$ combined with contrastenhanced CT is currently the gold standard technique for differentiating between diffuse and focal forms of congenital $\mathrm{HH}$ in infants [131]. However, such imaging should be performed only in centres with the necessary expertise, and the images should be interpreted only by experts in the field of combined PET and contrast-enhanced CT imaging.

The principle of this imaging technique is based on the fact that pancreatic islets take up L-DOPA and convert it into dopamine using the enzyme DOPA decarboxylase, which is expressed in islet cells. ${ }^{18} \mathrm{~F}$-DOPA is an analogue of DOPA and thus the positron-emitting compound is useful for tracking the uptake of this dopamine precursor. Both diffuse and focal diseases have a high DOPA decarboxylase activity.

Apart from differentiating diffuse and focal disease, ${ }^{18} \mathrm{~F}-\mathrm{DOPA}$ PET/CT simultaneously permits precise preoperative localisation of the lesion [132-135]. A meta-analysis reported the pooled sensitivity and specificity of ${ }^{18} \mathrm{~F}$-DOPA PET/CT in differentiating between focal and diffuse $\mathrm{HH}$ as $89 \%$ (95\% CI: 81-95\%) and $98 \%$ (95\% CI: 89-100\%), respectively [136]. The pooled accuracy in localizing focal $\mathrm{HH}$ was $80 \%$ (95\% CI: 71-88\%).

If facilities are available for rapid genetic testing, then ${ }^{18} \mathrm{~F}-\mathrm{DOPA}$ PET/CT should only be performed in those patients with paternally inherited, de novo or no identifiable $\mathrm{K}_{\mathrm{ATP}}$ channel mutations.

\section{Adult onset $\mathrm{HH}$}

Insulinoma is the most common cause for $\mathrm{HH}$ in adults. Surgery is the treatment of choice for insulinoma and has a relative high success rate. Based on the extent of surgery, lifelong treatment for diabetes mellitus may be required (near total pancreatectomy).

Preoperative accurate localisation is necessary for planning the surgical approach. Insulinoma can be localised using noninvasive [transabdominal Ultrasonography, Computed Tomography (CT) and/or Magnetic Resonance Imaging (MRI)] and invasive methods [Endoscopic Ultrasonography (EUS) and/or angiography and arterial stimulation venous sampling (ASVS)].

Invasive modalities are highly accurate in the preoperative localisation and have frequently been shown to be superior to noninvasive localisation techniques $[137,138]$. An innovative noninvasive technique, glucagon-like peptide-1 receptor (GLP1R) scintigraphy, has been reported to successfully localise small insulinomas pre- and intraoperatively and may affect the strategy of insulinoma localisation in the future $[139,140]$.

Medical treatment is also available but only for patients who are unable or unwilling to undergo surgical treatment, with variable response to diazoxide and octreotide. Very recently, there have been reports of improved glycaemia control with mTOR (mammalian target of rapamycin) inhibitors in patients with malignant insulinoma and refractory hypoglycaemia $[141,142]$. The clinical benefit is thought to be either due to the antitumor effect of mTOR inhibitor or a direct effect on glycaemic control. As functional insulin receptors are present on $\beta$-cells and mediate insulin-stimulated insulin production, mTOR inhibition downstream of insulin receptors may decrease insulin production and release $[143,144]$.

Patients with NIPHS usually require partial pancreatectomy to relieve further neuroglycopaenic attacks. However in some patients, diazoxide does seem to attenuate the insulin response to meals [95]. The treatment options for postprandial $\mathrm{HH}$ after gastric bypass surgery include modified low-carbohydrate diet, diazoxide, octreotide, $\alpha$-glucosidase inhibitors (such as acarbose), calcium-channel blockers (such as nifedipine), or post-operative feeding to the bypassed proximal gut by gastrostomy [145-147]. When medical treatment options fail, surgery (pancreatic resection or reversal of gastric bypass) has been advocated due to life threatening risk of neuroglycopaenia [17]. HH due to insulin autoimmune syndrome is managed with steroids [86].

\section{Conclusion}

$\nabla$

$\mathrm{HH}$ is a complex challenging disorder which requires early diagnosis to prevent brain injury especially in the childhood and adolescence. Despite the recent advances in understanding some of the causes of $\mathrm{HH}$ there are still a significant number of patients where the $\mathrm{HH}$ is still not established at a genetic level. Further research is required to develop novel therapies for children with the diffuse form of the disease.

\section{Conflict of Interest}

$\nabla$

The authors declare that they have no conflicts of interest in the authorship or publication of this contribution.

\section{References}

1 Aynsley-Green A, Hussain K, Hall J, Saudubray JM, Nihoul-Fekete C, De Lonlay-Debeney P, Brunelle F, Otonkoski T, Thornton P, Lindley KJ. Practical management of hyperinsulinism in infancy. Arch Dis Child Fetal Neonatal Ed 2000; 82: F98-F107

2 Hussain K, Bryan J, Christesen HT, Brusgaard K, Aguilar-Bryan L. Serum glucagon counterregulatory hormonal response to hypoglycemia is blunted in congenital hyperinsulinism. Diabetes 2005; 54 : 2946-2951

3 Hussain K, Hindmarsh P, Aynsley-Green A. Neonates with symptomatic hyperinsulinemic hypoglycemia generate inappropriately low serum cortisol counterregulatory hormonal responses. J Clin Endocrinol Metab 2003; 88: 4342-4347

4 Kapoor RR, Flanagan SE, James C, Shield J, Ellard S, Hussain K. Hyperinsulinaemic hypoglycaemia. Arch Dis Child 2009; 94: 450-457

5 James C, Kapoor RR, Ismail D, Hussain K. The genetic basis of congenital hyperinsulinism. J Med Genet 2009; 46: 289-299

6 Thomas PM, Cote GJ, Wohllk N, Haddad B, Mathew PM, Rabl W, Aguilar-Bryan L, Gagel RF, Bryan J. Mutations in the sulfonylurea receptor gene in familial persistent hyperinsulinemic hypoglycemia of infancy. Science 1995; 268: 426-429

7 Thomas P, Ye Y, Lightner E. Mutation of the pancreatic islet inward rectifier Kir6.2 also leads to familial persistent hyperinsulinemic hypoglycemia of infancy. Hum Mol Genet 1996; 5: 1809-1812 
8 Glaser B, Kesavan P, Heyman M, Davis E, Cuesta A, Buchs A, Stanley CA, Thornton PS, Permutt MA, Matschinsky FM, Herold KC. Familial hyperinsulinism caused by an activating glucokinase mutation. New Engl J Med 1998; 338: 226-230

9 Clayton PT, Eaton S, Aynsley-Green A, Edginton M, Hussain K, Krywawych S, Datta V, Malingre HE, Berger R, van den Berg IE. Hyperinsulinism in short-chain L-3-hydroxyacyl-CoA dehydrogenase deficiency reveals the importance of beta-oxidation in insulin secretion. J Clin Invest 2001; 108: 457-465

10 Stanley CA, Lieu YK, Hsu BY, Burlina AB, Greenberg CR, Hopwood NJ, Perlman K, Rich BH, Zammarchi E, Poncz M. Hyperinsulinism and hyperammonemia in infants with regulatory mutations of the glutamate dehydrogenase gene. New Engl J Med 1998; 338: 1352-1357

11 Kapoor RR, Flanagan SE, Arya VB, Shield JP, Ellard S, Hussain K. Clinical and molecular characterisation of 300 patients with congenital hyperinsulinism. Eur J Endocrinol 2013; 168: 557-564

12 Snider KE, Becker S, Boyajian L, Shyng SL, MacMullen C, Hughes N, Ganapathy K, Bhatti T, Stanley CA, Ganguly A. Genotype and phenotype correlations in 417 children with congenital hyperinsulinism. J Clin Endocrinol Metab 2013; 98: E355-E363

13 Rahier J, Guiot Y, Sempoux C. Persistent hyperinsulinaemic hypoglycaemia of infancy: a heterogeneous syndrome unrelated to nesidioblastosis. Arch Dis Child Fetal Neonatal Ed 2000; 82: F108-F112

14 Otonkoski T, Nanto-Salonen K, Seppanen M, Veijola R, Huopio H, Hussain $K$, Tapanainen P, Eskola O, Parkkola R, Ekstrom K, Guiot $Y$, Rahier $J$, Laakso M, Rintala $R$, Nuutila P, Minn $H$. Noninvasive diagnosis of focal hyperinsulinism of infancy with [18F]-DOPA positron emission tomography. Diabetes 2006; 55: 13-18

15 Service FJ, Natt N, Thompson GB, Grant CS, van Heerden JA, Andrews $J C$, Lorenz E, Terzic A, Lloyd RV. Noninsulinoma pancreatogenous hypoglycemia: a novel syndrome of hyperinsulinemic hypoglycemia in adults independent of mutations in Kir6.2 and SUR1 genes. J Clin Endocrinol Metab 1999; 84: 1582-1589

16 Service GJ, Thompson GB, Service FJ, Andrews JC, Collazo-Clavell ML, Lloyd RV. Hyperinsulinemic hypoglycemia with nesidioblastosis after gastric-bypass surgery. New Engl J Med 2005; 353: 249-254

17 Patti ME, McMahon G, Mun EC, Bitton A, Holst JJ, Goldsmith J, Hanto $D W$, Callery $M$, Arky $R$, Nose V, Bonner-Weir $S$, Goldfine AB. Severe hypoglycaemia post-gastric bypass requiring partial pancreatectomy: evidence for inappropriate insulin secretion and pancreatic islet hyperplasia. Diabetologia 2005; 48: 2236-2240

18 Hojlund $K$, Hansen T, Lajer M, Henriksen JE, Levin K, Lindholm J, Pedersen 0 , Beck-Nielsen $H$. A novel syndrome of autosomal-dominant hyperinsulinemic hypoglycemia linked to a mutation in the human insulin receptor gene. Diabetes 2004; 53: 1592-1598

19 Dunne MJ, Cosgrove KE, Shepherd RM, Aynsley-Green A, Lindley KJ. Hyperinsulinism in infancy: from basic science to clinical disease. Physiol Rev 2004; 84: 239-275

20 Matschinsky FM. Banting Lecture 1995. A lesson in metabolic regulation inspired by the glucokinase glucose sensor paradigm. Diabetes 1996; 45: 223-241

21 Cryer PE, Axelrod L, Grossman AB, Heller SR, Montori VM, Seaquist $E R$, Service FJ. Evaluation and management of adult hypoglycemic disorders: an Endocrine Society Clinical Practice Guideline. J Clin Endocrinol Metab 2009; 94: 709-728

22 Cryer PE. Glucose counterregulation: prevention and correction of hypoglycemia in humans. Am J Physiol 1993; 264: E149-E155

23 Malaisse WJ, Sener A, Herchuelz A, Hutton JC. Insulin release: the fuel hypothesis. Metabolism 1979; 28: 373-386

24 Dunne MJ, Petersen $\mathrm{OH}$. Potassium selective ion channels in insulinsecreting cells: physiology, pharmacology and their role in stimulussecretion coupling. Biochim Biophys Acta 1991; 1071: 67-82

25 Inagaki N, Gonoi T, Clement JPt, Namba N, Inazawa J, Gonzalez G, Aguilar-Bryan L, Seino S, Bryan J. Reconstitution of IKATP: an inward rectifier subunit plus the sulfonylurea receptor. Science 1995; 270: 1166-1170

26 Straub SG, Cosgrove KE, Ammala C, Shepherd RM, O'Brien RE, Barnes $P D$, Kuchinski N, Chapman JC, Schaeppi M, Glaser B, Lindley KJ, Sharp GW, Aynsley-Green A, Dunne MJ. Hyperinsulinism of infancy: the regulated release of insulin by KATP channel-independent pathways. Diabetes 2001; 50: 329-339

27 Gembal M, Detimary P, Gilon P, Gao ZY, Henquin JC. Mechanisms by which glucose can control insulin release independently from its action on adenosine triphosphate-sensitive $\mathrm{K}+$ channels in mouse B cells. J Clin Invest 1993; 91: 871-880

28 Aizawa T, Sato Y, Ishihara F, Taguchi N, Komatsu M, Suzuki N, Hashizume K, Yamada T. ATP-sensitive $\mathrm{K}+$ channel-independent glucose action in rat pancreatic beta-cell. Am J Physiol 1994; 266: C622-C627
29 Ammala C, Eliasson L, Bokvist K, Berggren PO, Honkanen RE, Sjoholm $A$, Rorsman P. Activation of protein kinases and inhibition of protein phosphatases play a central role in the regulation of exocytosis in mouse pancreatic beta cells. Proc Natl Acad Sci USA 1994; 91: 4343-4347

30 Yajima H, Komatsu M, Schermerhorn T, Aizawa T, Kaneko T, Nagai $M$, Sharp GW, Hashizume K. cAMP enhances insulin secretion by an action on the ATP-sensitive $\mathrm{K}+$ channel-independent pathway of glucose signaling in rat pancreatic islets. Diabetes 1999; 48: 1006-1012

31 Macfarlane WM, Shepherd RM, Cosgrove KE, James RF, Dunne MJ, Docherty K. Glucose modulation of insulin mRNA levels is dependent on transcription factor PDX-1 and occurs independently of changes in intracellular Ca2+. Diabetes 2000; 49: 418-423

32 Macfarlane WM, McKinnon CM, Felton-Edkins ZA, Cragg H, James RF, Docherty $K$. Glucose stimulates translocation of the homeodomain transcription factor PDX1 from the cytoplasm to the nucleus in pancreatic beta-cells. J Biol Chem 1999; 274: 1011-1016

33 Melloul D, Ben-Neriah Y, Cerasi E. Glucose modulates the binding of an islet-specific factor to a conserved sequence within the rat I and the human insulin promoters. Proc Natl Acad Sci USA 1993; 90: 3865-3869

34 Shepherd RM, Cosgrove KE, O'Brien RE, Barnes PD, Ammala C, Dunne $M J$. Hyperinsulinism of infancy: towards an understanding of unregulated insulin release. European Network for Research into Hyperinsulinism in Infancy. Arch Dis Child Fetal Neonatal Ed 2000; 82: F87-F97

35 Choufani S, Shuman C, Weksberg $R$. Beckwith-Wiedemann syndrome. Am J Med Genet C Semin Med Genet 2010; 154C: 343-354

36 Kapoor RR, Flanagan SE, Fulton P, Chakrapani A, Chadefaux B, BenOmran T, Banerjee I, Shield JP, Ellard S, Hussain K. Hyperinsulinismhyperammonaemia syndrome: novel mutations in the GLUD1 gene and genotype-phenotype correlations. Eur J Endocrinol 2009; 161 : 731-735

37 Veit F, Heine RG, Catto-Smith AG. Dumping syndrome after Nissen fundoplication. J Paediatr Child Health 1994; 30: 182-185

38 Wiesli P, Schmid C, Perren A, Pfammatter T, Spinas GA, Keller U. Hypoglycemia in response to glucose and glucagon in insulinoma patients with a negative prolonged fast: functional and morphological properties. J Endocrinol Invest 2004; 27: 832-838

39 Nestorowicz A, Wilson BA, Schoor KP, Inoue $H$, Glaser B, Landau $H$, Stanley CA, Thornton PS, Clement JPt, Bryan J, Aguilar-Bryan L, Permutt $M A$. Mutations in the sulonylurea receptor gene are associated with familial hyperinsulinism in Ashkenazi Jews. Hum Mol Genet 1996; 5: $1813-1822$

40 Cartier EA, Conti LR, Vandenberg CA, Shyng SL. Defective trafficking and function of KATP channels caused by a sulfonylurea receptor 1 mutation associated with persistent hyperinsulinemic hypoglycemia of infancy. Proc Natl Acad Sci USA 2001; 98: 2882-2887

41 Partridge CJ, Beech DJ, Sivaprasadarao A. Identification and pharmacological correction of a membrane trafficking defect associated with a mutation in the sulfonylurea receptor causing familial hyperinsulinism. J Biol Chem 2001; 276: 35947-35952

42 Shyng SL, Ferrigni T, Shepard JB, Nestorowicz A, Glaser B, Permutt MA, Nichols $C G$. Functional analyses of novel mutations in the sulfonylurea receptor 1 associated with persistent hyperinsulinemic hypoglycemia of infancy. Diabetes 1998; 47: 1145-1151

43 Dunne MJ, Kane C, Shepherd RM, Sanchez JA, James RF, Johnson PR, Aynsley-Green A, Lu S, Clement JPt, Lindley KJ, Seino S, Aguilar-Bryan $L$. Familial persistent hyperinsulinemic hypoglycemia of infancy and mutations in the sulfonylurea receptor. N Engl J Med 1997; 336: 703-706

44 Dekel B, Lubin D, Modan-Moses D, Quint J, Glaser B, Meyerovitch J. Compound heterozygosity for the common sulfonylurea receptor mutations can cause mild diazoxide-sensitive hyperinsulinism. Clin Pediatr (Phila) 2002; 41: 183-186

45 Huopio H, Reimann F, Ashfield R, Komulainen J, Lenko HL, Rahier J, Vauhkonen I, Kere J, Laakso M, Ashcroft F, Otonkoski T. Dominantly inherited hyperinsulinism caused by a mutation in the sulfonylurea receptor type 1 . J Clin Invest 2000; 106: 897-906

46 Pinney SE, MacMullen C, Becker S, Lin YW, Hanna C, Thornton P, Ganguly A, Shyng SL, Stanley CA. Clinical characteristics and biochemical mechanisms of congenital hyperinsulinism associated with dominant KATP channel mutations. J Clin Invest 2008; 118: 2877-2886

47 Kapoor RR, Flanagan SE, James CT, McKiernan J, Thomas AM, Harmer SC, Shield JP, Tinker A, Ellard S, Hussain K. Hyperinsulinaemic hypoglycaemia and diabetes mellitus due to dominant ABCC8/KCNJ11 mutations. Diabetologia 2011; 54: 2575-2583 
48 Treberg JR, Clow KA, Greene KA, Brosnan ME, Brosnan JT. Systemic activation of glutamate dehydrogenase increases renal ammoniagenesis: implications for the hyperinsulinism/hyperammonemia syndrome. Am J Physiol Endocrinol Metab 2010; 298: E1219-E1225

49 MacMullen C, Fang J, Hsu BY, Kelly A, de Lonlay-Debeney P, Saudubray JM, Ganguly A, Smith TJ, Stanley CA. Hyperinsulinism/hyperammonemia syndrome in children with regulatory mutations in the inhibitory guanosine triphosphate-binding domain of glutamate dehydrogenase. J Clin Endocrinol Metab 2001; 86: 1782-1787

50 Stanley CA, Fang J, Kutyna K, Hsu BY, Ming JE, Glaser B, Poncz M. Molecular basis and characterization of the hyperinsulinism/hyperammonemia syndrome: predominance of mutations in exons 11 and 12 of the glutamate dehydrogenase gene. HI/HA Contributing Investigators. Diabetes 2000; 49: 667-673

51 Palladino AA, Stanley CA. The hyperinsulinism/hyperammonemia syndrome. Rev Endocr Metab Disord 2010; 11: 171-178

52 Raizen DM, Brooks-Kayal A, Steinkrauss L, Tennekoon GI, Stanley CA, Kelly $A$. Central nervous system hyperexcitability associated with glutamate dehydrogenase gain of function mutations. J Pediatr 2005; 146: 388-394

53 Kapoor RR, Flanagan SE, Fulton P, Chakrapani A, Chadefaux B, BenOmran T, Banerjee I, Shield JP, Ellard S, Hussain K. Hyperinsulinismhyperammonaemia syndrome: novel mutations in the GLUD1 gene and genotype-phenotype correlations. Eur J Endocrinol 2009; 161: 731-735

54 Bahi-Buisson N, El Sabbagh S, Soufflet C, Escande F, Boddaert N, Valayannopoulos V, Bellane-Chantelot $C$, Lascelles $K$, Dulac $O$, Plouin $P$, de Lonlay $P$. Myoclonic absence epilepsy with photosensitivity and a gain of function mutation in glutamate dehydrogenase. Seizure 2008; 17: 658-664

55 Davis EA, Cuesta-Munoz A, Raoul M, Buettger C, Sweet I, Moates M, Magnuson MA, Matschinsky FM. Mutants of glucokinase cause hypoglycaemia- and hyperglycaemia syndromes and their analysis illuminates fundamental quantitative concepts of glucose homeostasis. Diabetologia 1999; 42: 1175-1186

56 Cuesta-Munoz AL, Huopio H, Otonkoski T, Gomez-Zumaquero JM, Nanto-Salonen K, Rahier J, Lopez-Enriquez S, Garcia-Gimeno MA, Sanz P, Soriguer FC, Laakso M. Severe persistent hyperinsulinemic hypoglycemia due to a de novo glucokinase mutation. Diabetes 2004; 53: 2164-2168

57 Christesen $H B$, Jacobsen BB, Odili S, Buettger C, Cuesta-Munoz A, Hansen T, Brusgaard K, Massa O, Magnuson MA, Shiota C, Matschinsky FM, Barbetti F. The second activating glucokinase mutation (A456V): implications for glucose homeostasis and diabetes therapy. Diabetes 2002; 51: 1240-1246

58 Dullaart RP, Hoogenberg K, Rouwe CW, Stulp BK. Family with autosomal dominant hyperinsulinism associated with A456V mutation in the glucokinase gene. J Intern Med 2004; 255: 143-145

59 Glaser B, Kesavan P, Heyman M, Davis E, Cuesta A, Buchs A, Stanley CA, Thornton PS, Permutt MA, Matschinsky FM, Herold KC. Familial hyperinsulinism caused by an activating glucokinase mutation. $\mathrm{N}$ Engl J Med 1998; 338: 226-230

60 Christesen HB, Tribble ND, Molven A, Siddiqui J, Sandal T, Brusgaard K, Ellard S, Njolstad PR, Alm J, Brock Jacobsen B, Hussain K, Gloyn $A L$. Activating glucokinase (GCK) mutations as a cause of medically responsive congenital hyperinsulinism: prevalence in children and characterisation of a novel GCK mutation. Eur J Endocrinol 2008; 159: 27-34

61 Sladek FM, Zhong WM, Lai E, Darnell JE Jr. Liver-enriched transcription factor HNF-4 is a novel member of the steroid hormone receptor superfamily. Genes Dev 1990; 4: 2353-2365

62 Xanthopoulos KG, Prezioso VR, Chen WS, Sladek FM, Cortese R, Darnell $J E J r$. The different tissue transcription patterns of genes for HNF-1, C/EBP, HNF-3, and HNF-4, protein factors that govern liver-specific transcription. Proc Natl Acad Sci USA 1991; 88: 3807-3811

63 Kuo CJ, Conley PB, Chen L, Sladek FM, Darnell JE Jr, Crabtree GR. A transcriptional hierarchy involved in mammalian cell-type specification. Nature 1992; 355: 457-461

64 Kapoor RR, Locke J, Colclough K, Wales J, Conn JJ, Hattersley AT, Ellard S, Hussain K. Persistent hyperinsulinemic hypoglycemia and maturityonset diabetes of the young due to heterozygous HNF4A mutations. Diabetes 2008; 57: 1659-1663

65 Pearson ER, Boj SF, Steele AM, Barrett T, Stals K, Shield JP, Ellard S, Ferrer $J$, Hattersley AT. Macrosomia and hyperinsulinaemic hypoglycaemia in patients with heterozygous mutations in the HNF4A gene. PLoS Med 2007; 4: e118
66 Stanescu DE, Hughes N, Kaplan B, Stanley CA, De Leon DD. Novel Presentations of Congenital Hyperinsulinism due to Mutations in the MODY genes: HNF1A and HNF4A. J Clin Endocrinol Metab 2012; 97: E2026-E2030

67 Gupta RK, Vatamaniuk MZ, Lee CS, Flaschen RC, Fulmer JT, Matschinsky FM, Duncan SA, Kaestner KH. The MODY1 gene HNF-4alpha regulates selected genes involved in insulin secretion. J Clin Invest 2005; 115: 1006-1015

68 Gremlich S, Nolan C, Roduit $R$, Burcelin R, Peyot ML, DelghingaroAugusto V, Desvergne B, Michalik L, Prentki M, Wahli W. Pancreatic islet adaptation to fasting is dependent on peroxisome proliferatoractivated receptor alpha transcriptional up-regulation of fatty acid oxidation. Endocrinology 2005; 146: 375-382

69 Hussain K, Clayton PT, Krywawych S, Chatziandreou I, Mills P, Ginbey $D W$, Geboers AJ, Berger R, van den Berg IE, Eaton S. Hyperinsulinism of infancy associated with a novel splice site mutation in the SCHAD gene. J Pediatr 2005; 146: 706-708

70 Molven A, Matre GE, Duran M, Wanders RJ, Rishaug U, Njolstad PR, Jellum $E$, Sovik $O$. Familial hyperinsulinemic hypoglycemia caused by a defect in the SCHAD enzyme of mitochondrial fatty acid oxidation. Diabetes 2004; 53: 221-227

71 Lantz KA, Vatamaniuk MZ, Brestelli JE, Friedman JR, Matschinsky FM, Kaestner $\mathrm{KH}$. Foxa2 regulates multiple pathways of insulin secretion. J Clin Invest 2004; 114: 512-520

72 Sund NJ, Vatamaniuk MZ, Casey M, Ang SL, Magnuson MA, Stoffers DA, Matschinsky FM, Kaestner KH. Tissue-specific deletion of Foxa2 in pancreatic beta cells results in hyperinsulinemic hypoglycemia. Genes Dev 2001; 15: 1706-1715

73 Kapoor RR, James C, Flanagan SE, Ellard S, Eaton S, Hussain K. 3-Hydroxyacyl-coenzyme A dehydrogenase deficiency and hyperinsulinemic hypoglycemia: characterization of a novel mutation and severe dietary protein sensitivity. J Clin Endocrinol Metab 2009; 94 : 2221-2225

74 Li C, Chen P, Palladino A, Narayan S, Russell LK, Sayed S, Xiong G, Chen J, Stokes D, Butt YM, Jones PM, Collins HW, Cohen NA, Cohen AS, Nissim I, Smith TJ, Strauss AW, Matschinsky FM, Bennett MJ, Stanley CA. Mechanism of hyperinsulinism in short-chain 3-hydroxyacyl-CoA dehydrogenase deficiency involves activation of glutamate dehydrogenase. J Biol Chem 2010; 285: 31806-31818

75 Heslegrave AJ, Kapoor RR, Eaton S, Chadefaux B, Ackay T, Simsek E, Flanagan SE, Ellard S, Hussain K. Leucine-sensitive hyperinsulinaemic hypoglycaemia in patients with loss of function mutations in 3-Hydroxyacyl-CoA Dehydrogenase. Orphanet J Rare Dis 2012; 7: 25

76 Flanagan SE, Patch AM, Locke JM, Akcay T, Simsek E, Alaei M, Yekta Z, Desai M, Kapoor RR, Hussain K, Ellard S. Genome-wide homozygosity analysis reveals HADH mutations as a common cause of diazoxideresponsive hyperinsulinemic-hypoglycemia in consanguineous pedigrees. J Clin Endocrinol Metab 2011; 96: E498-E502

77 Otonkoski T, Kaminen N, Ustinov J, Lapatto R, Meissner T, Mayatepek E, Kere J, Sipila I. Physical exercise-induced hyperinsulinemic hypoglycemia is an autosomal-dominant trait characterized by abnormal pyruvate-induced insulin release. Diabetes 2003; 52: 199-204

78 Meissner T, Friedmann B, Okun JG, Schwab MA, Otonkoski T, Bauer $T$, Bartsch $P$, Mayatepek E. Massive insulin secretion in response to anaerobic exercise in exercise-induced hyperinsulinism. Horm Metab Res 2005; 37: 690-694

79 Ishihara $H$, Wang $H$, Drewes $L R$, Wollheim CB. Overexpression of monocarboxylate transporter and lactate dehydrogenase alters insulin secretory responses to pyruvate and lactate in beta cells. J Clin Invest 1999; 104: 1621-1629

80 Service FJ, McMahon MM, O'Brien PC, Ballard DJ. Functioning insulinoma - incidence, recurrence, and long-term survival of patients: a 60-year study. Mayo Clin Proc 1991; 66: 711-719

81 Kar P, Price P, Sawers S, Bhattacharya S, Reznek RH, Grossman AB. Insulinomas may present with normoglycemia after prolonged fasting but glucose-stimulated hypoglycemia. J Clin Endocrinol Metab 2006; 91: 4733-4736

82 Samuk I, Afriat R, Horne T, Bistritzer T, Barr J, Vinograd I. Dumping syndrome following Nissen fundoplication, diagnosis, and treatment. J Pediatr Gastroenterol Nutr 1996; 23: 235-240

83 Palladino AA, Sayed S, Levitt Katz LE, Gallagher PR, De Leon DD. Increased glucagon-like peptide-1 secretion and postprandial hypoglycemia in children after Nissen fundoplication. J Clin Endocrinol Metab 2009; 94: 39-44

84 Kneepkens CM, Fernandes J, Vonk RJ. Dumping syndrome in children. Diagnosis and effect of glucomannan on glucose tolerance and absorption. Acta Paediatr Scand 1988; 77: 279-286 
85 Basu A, Service FJ, Yu L, Heser D, Ferries LM, Eisenbarth G. Insulin autoimmunity and hypoglycemia in seven white patients. Endocr Pract 2005; 11: 97-103

86 Lupsa BC, Chong AY, Cochran EK, Soos MA, Semple RK, Gorden P. Autoimmune forms of hypoglycemia. Medicine (Baltimore) 2009; 88: $141-153$

87 Marsk R, Jonas E, Rasmussen F, Naslund E. Nationwide cohort study of post-gastric bypass hypoglycaemia including 5040 patients undergoing surgery for obesity in 1986-2006 in Sweden. Diabetologia 2010; 53: 2307-2311

88 Goldfine $A B$, Mun EC, Devine E, Bernier R, Baz-Hecht $M$, Jones DB, Schneider BE, Holst JJ, Patti ME. Patients with neuroglycopenia after gastric bypass surgery have exaggerated incretin and insulin secretory responses to a mixed meal. J Clin Endocrinol Metab 2007; 92: 4678-4685

89 Laferrere B, Heshka S, Wang K, Khan Y, McGinty J, Teixeira J, Hart AB, Olivan $B$. Incretin levels and effect are markedly enhanced 1 month after Roux-en-Y gastric bypass surgery in obese patients with type 2 diabetes. Diabetes Care 2007; 30: 1709-1716

90 Laferrere B, Teixeira J, McGinty J, Tran H, Egger JR, Colarusso A, Kovack $B$, Bawa B, Koshy N, Lee H, Yapp K, Olivan B. Effect of weight loss by gastric bypass surgery versus hypocaloric diet on glucose and incretin levels in patients with type 2 diabetes. J Clin Endocrinol Metab 2008; 93: 2479-2485

91 Rabiee A, Magruder JT, Salas-Carrillo R, Carlson O, Egan JM, Askin FB, Elahi D, Andersen DK. Hyperinsulinemic hypoglycemia after Roux-enY gastric bypass: unraveling the role of gut hormonal and pancreatic endocrine dysfunction. J Surg Res 2011; 167: 199-205

92 Perfetti R, Zhou J, Doyle ME, Egan JM. Glucagon-like peptide-1 induces cell proliferation and pancreatic-duodenum homeobox-1 expression and increases endocrine cell mass in the pancreas of old, glucoseintolerant rats. Endocrinology 2000; 141: 4600-4605

93 Drucker DJ. Glucagon-like peptides: regulators of cell proliferation, differentiation, and apoptosis. Mol Endocrinol 2003; 17: 161-171

94 Rumilla KM, Erickson LA, Service FJ, Vella A, Thompson GB, Grant CS, Lloyd $R V$. Hyperinsulinemic hypoglycemia with nesidioblastosis: histologic features and growth factor expression. Modern Pathol 2009; 22: 239-245

95 Won JG, Tseng HS, Yang AH, Tang KT, Jap TS, Lee CH, Lin HD, Burcus N, Pittenger G, Vinik A. Clinical features and morphological characterization of 10 patients with noninsulinoma pancreatogenous hypoglycaemia syndrome (NIPHS). Clin Endocrinol (Oxf) 2006; 65: 566-578

96 Verkarre V, Fournet JC, de Lonlay P, Gross-Morand MS, Devillers M, Rahier J, Brunelle F, Robert JJ, Nihoul-Fekete C, Saudubray JM, Junien $C$. Paternal mutation of the sulfonylurea receptor (SUR1) gene and maternal loss of 11p15 imprinted genes lead to persistent hyperinsulinism in focal adenomatous hyperplasia. J Clin Invest 1998; 102 : 1286-1291

97 Fournet JC, Mayaud C, de Lonlay P, Gross-Morand MS, Verkarre V, Castanet M, Devillers M, Rahier J, Brunelle F, Robert JJ, Nihoul-Fekete C, Saudubray JM, Junien C. Unbalanced expression of 11p15 imprinted genes in focal forms of congenital hyperinsulinism: association with a reduction to homozygosity of a mutation in ABCC8 or KCNJ11. Am J Pathol 2001; 158: 2177-2184

98 Ismail D, Smith VV, de Lonlay P, Ribeiro MJ, Rahier J, Blankenstein $O$, Flanagan SE, Bellanne-Chantelot C, Verkarre V, Aigrain Y, Pierro A, Ellard S, Hussain K. Familial focal congenital hyperinsulinism. J Clin Endocrinol Metab 2011; 96: 24-28

99 Finegold DN, Stanley CA, Baker L. Glycemic response to glucagon during fasting hypoglycemia: an aid in the diagnosis of hyperinsulinism. J Pediatr 1980; 96: 257-259

100 Levitt Katz LE, Satin-Smith MS, Collett-Solberg P, Thornton PS, Baker $L$, Stanley $C A$, Cohen $P$. Insulin-like growth factor binding protein-1 levels in the diagnosis of hypoglycemia caused by hyperinsulinism. J Pediatr 1997; 131: 193-199

101 Stanley CA. Hyperinsulinism/hyperammonemia syndrome: insights into the regulatory role of glutamate dehydrogenase in ammonia metabolism. Mol Genet Metab 2004; 81 (Suppl 1): S45-S51

102 Hsu BY, Kelly A, Thornton PS, Greenberg CR, Dilling LA, Stanley CA. Protein-sensitive and fasting hypoglycemia in children with the hyperinsulinism/hyperammonemia syndrome. J Pediatr 2001; 138: 383-389

103 MacMullen C, Fang J, Hsu BY, Kelly A, de Lonlay-Debeney P, Saudubray JM, Ganguly A, Smith TJ, Stanley CA. Hyperinsulinism/hyperammonemia syndrome in children with regulatory mutations in the inhibitory guanosine triphosphate-binding domain of glutamate dehydrogenase. J Clin Endocrinol Metab 2001; 86: 1782-1787

104 Service FJ, Natt N. The prolonged fast. J Clin Endocrinol Metab 2000; 85: 3973-3974
105 Touati G, Poggi-Travert F, Ogier de Baulny H, Rahier J, Brunelle F, Nihoul-Fekete C, Czernichow P, Saudubray JM. Long-term treatment of persistent hyperinsulinaemic hypoglycaemia of infancy with diazoxide: a retrospective review of 77 cases and analysis of efficacypredicting criteria. Eur J Pediatr 1998; 157: 628-633

106 Grant DB, Dunger DB, Burns EC. Long-term treatment with diazoxide in childhood hyperinsulinism. Acta Endocrinol Suppl (Copenh) 1986; 279: 340-345

107 De Leon DD, Stanley CA. Mechanisms of Disease: advances in diagnosis and treatment of hyperinsulinism in neonates. Nat Clin Pract Endocrinol Metab 2007; 3: 57-68

108 Laje P, Halaby L, Adzick NS, Stanley CA. Necrotizing enterocolitis in neonates receiving octreotide for the management of congenital hyperinsulinism. Pediatr Diabetes 2010; 11: 142-147

109 Vezzosi D, Bennet A, Rochaix P, Courbon F, Selves J, Pradere B, Buscail L, Susini C, Caron P. Octreotide in insulinoma patients: efficacy on hypoglycemia, relationships with Octreoscan scintigraphy and immunostaining with anti-sst2A and anti-sst5 antibodies. Eur J Endocrinol 2005; 152: 757-767

110 Yorifuji T, Kawakita R, Hosokawa Y, Fujimaru R, Matsubara K, Aizu K, Suzuki S, Nagasaka H, Nishibori H, Masue M. Efficacy and safety of long-term, continuous subcutaneous octreotide infusion for patients with different subtypes of KATP-channel hyperinsulinism. Clin Endocrinol (Oxf) 2013; 78: 891-897

111 Modan-Moses D, Koren I, Mazor-Aronovitch K, Pinhas-Hamiel O Landau $H$. Treatment of congenital hyperinsulinism with lanreotide acetate (Somatuline Autogel). J Clin Endocrinol Metab 2011; 96: 2312-2317

112 Le Quan Sang KH, Arnoux JB, Mamoune A, Saint-Martin C, BellanneChantelot C, Valayannopoulos V, Brassier A, Kayirangwa H, Barbier V, Broissand C, Fabreguettes JR, Charron B, Thalabard JC, de Lonlay P. Successful treatment of congenital hyperinsulinism with long-acting release octreotide. Eur J Endocrinol 2012; 166: 333-339

113 Mohnike K, Blankenstein O, Pfuetzner A, Potzsch S, Schober E, Steiner $S$, Hardy OT, Grimberg A, van Waarde WM. Long-term non-surgical therapy of severe persistent congenital hyperinsulinism with glucagon. Horm Res 2008; 70: 59-64

114 De Leon DD, Li C, Delson MI, Matschinsky FM, Stanley CA, Stoffers DA Exendin-(9-39) corrects fasting hypoglycemia in SUR-1-/- mice by lowering cAMP in pancreatic beta-cells and inhibiting insulin secretion. J Biol Chem 2008; 283: 25786-25793

115 Calabria AC, Li C, Gallagher PR, Stanley CA, De Leon DD. GLP-1 receptor antagonist exendin-(9-39) elevates fasting blood glucose levels in congenital hyperinsulinism owing to inactivating mutations in the ATP-sensitive K+ channel. Diabetes 2012; 61: 2585-2591

116 Al-Shanafey S. Laparoscopic vs. open pancreatectomy for persistent hyperinsulinemic hypoglycemia of infancy. J Pediatr Surg 2009; 44: 957-961

117 Pierro A, Nah SA. Surgical management of congenital hyperinsulinism of infancy. Semin Pediatr Surg 2011; 20: 50-53

118 Goossens A, Gepts W, Saudubray JM, Bonnefont JP, Nihoul F, Heitz $P U$, Kloppel G. Diffuse and focal nesidioblastosis. A clinicopathological study of 24 patients with persistent neonatal hyperinsulinemic hypoglycemia. Am J Surg Pathol 1989; 13: 766-775

119 Rahier J, Guiot Y, Sempoux C. Persistent hyperinsulinaemic hypoglycaemia of infancy: a heterogeneous syndrome unrelated to nesidioblastosis. Arch Dis Child Fetal Neonat Ed 2000; 82: F108-F112

120 Kloppel G, Reinecke-Luthge A, Koschoreck F. Focal and Diffuse Beta Cell Changes in Persistent Hyperinsulinemic Hypoglycemia of Infancy. Endocr Pathol 1999; 10: 299-304

121 Ismail D, Kapoor RR, Smith VV, Ashworth M, Blankenstein O, Pierro A, Flanagan SE, Ellard S, Hussain K. The heterogeneity of focal forms of congenital hyperinsulinism. J Clin Endocrinol Metab 2012; 97: E94-E99

122 Hardy OT, Hernandez-Pampaloni M, Saffer JR, Suchi M, Ruchelli E, Zhuang H, Ganguly A, Freifelder R, Adzick NS, Alavi A, Stanley CA. Diagnosis and localization of focal congenital hyperinsulinism by 18F-fluorodopa PET scan. J Pediatr 2007; 150: 140-145

123 Barthlen W, Blankenstein O, Mau H, Koch M, Hohne C, Mohnike W, Eberhard T, Fuechtner F, Lorenz-Depiereux B, Mohnike K. Evaluation of [18F]fluoro-L-DOPA positron emission tomography-computed tomography for surgery in focal congenital hyperinsulinism. J Clin Endocrinol Metab 2008; 93: 869-875

124 Mohnike K, Blankenstein O, Christesen HT, De Lonlay J, Hussain K, Koopmans KP, Minn H, Mohnike W, Mutair A, Otonkoski T, Rahier J, Ribeiro M, Schoenle E, Fekete CN. Proposal for a standardized protocol for 18F-DOPA-PET (PET/CT) in congenital hyperinsulinism. Horm Res 2006; 66: 40-42 
125 Rahier J, Guiot Y, Sempoux C. Morphologic analysis of focal and diffuse forms of congenital hyperinsulinism. Semin Pediatr Surg 2011; 20: $3-12$

126 Sempoux C, Capito C, Bellanne-Chantelot C, Verkarre V, de Lonlay P, Aigrain Y, Fekete C, Guiot Y, Rahier J. Morphological mosaicism of the pancreatic islets: a novel anatomopathological form of persistent hyperinsulinemic hypoglycemia of infancy. J Clin Endocrinol Metab 2011; 96: 3785-3793

127 Henquin JC, Sempoux C, Marchandise J, Godecharles S, Guiot Y, Nenquin $M$, Rahier J. Congenital Hyperinsulinism Caused by Hexokinase I Expression or Glucokinase-Activating Mutation in a Subset of betaCells. Diabetes 2013; 62: 1689-1696

128 Beltrand J, Caquard M, Arnoux JB, Laborde K, Velho G, Verkarre V, Rahier J, Brunelle F, Nihoul-Fekete C, Saudubray JM, Robert JJ, de Lonlay $P$. Glucose metabolism in 105 children and adolescents after pancreatectomy for congenital hyperinsulinism. Diabetes Care 2012; 35: 198-203

129 de Lonlay P, Fournet JC, Rahier J, Gross-Morand MS, Poggi-Travert F, Foussier V, Bonnefont JP, Brusset MC, Brunelle F, Robert JJ, NihoulFekete C, Saudubray JM, Junien C. Somatic deletion of the imprinted $11 \mathrm{p} 15$ region in sporadic persistent hyperinsulinemic hypoglycemia of infancy is specific of focal adenomatous hyperplasia and endorses partial pancreatectomy. J Clin Invest 1997; 100: 802-807

130 Flanagan SE, Xie W, Caswell R, Damhuis A, Vianey-Saban C, Akcay T, Darendeliler F, Bas F, Guven A, Siklar Z, Ocal G, Berberoglu M, Murphy N, O'Sullivan M, Green A, Clayton PE, Banerjee I, Clayton PT, Hussain $K$, Weedon MN, Ellard S. Next-generation sequencing reveals deep intronic cryptic ABCC8 and HADH splicing founder mutations causing hyperinsulinism by pseudoexon activation. Am J Hum Genet 2013; 92: 131-136

131 Kapoor RR, James C, Hussain K. Advances in the diagnosis and management of hyperinsulinemic hypoglycemia. Nat Clin Pract Endocrinol Metab 2009; 5: 101-112

132 Hardy OT, Hernandez-Pampaloni M, Saffer JR, Scheuermann JS, Ernst LM, Freifelder R, Zhuang H, MacMullen C, Becker S, Adzick NS, Divgi C, Alavi A, Stanley CA. Accuracy of [18F]fluorodopa positron emission tomography for diagnosing and localizing focal congenital hyperinsulinism. J Clin Endocrinol Metab 2007; 92: 4706-4711

133 Laje P, States LJ, Zhuang H, Becker SA, Palladino AA, Stanley CA, Adzick NS. Accuracy of PET/CT Scan in the diagnosis of the focal form of congenital hyperinsulinism. J Pediatr Surg 2013; 48: 388-393

134 Meintjes M, Endozo R, Dickson J, Erlandsson K, Hussain K, Townsend C, Menezes L, Bomanji J. 18F-DOPA PET and enhanced CT imaging for congenital hyperinsulinism: initial UK experience from a technologist's perspective. Nucl Med Commun 2013; 34: 601-608

135 Ribeiro MJ, Boddaert N, Bellanne-Chantelot C, Bourgeois S, Valayannopoulos V, Delzescaux T, Jaubert F, Nihoul-Fekete C, Brunelle F, De Lonlay $P$. The added value of [18F]fluoro-L-DOPA PET in the diagnosis of hyperinsulinism of infancy: a retrospective study involving 49 children. Eur J Nucl Med Mol Imaging 2007; 34: 2120-2128
136 Treglia G, Mirk P, Giordano A, Rufini V. Diagnostic performance of fluorine-18-dihydroxyphenylalanine positron emission tomography in diagnosing and localizing the focal form of congenital hyperinsulinism: a meta-analysis. Pediatr Radiol 2012; 42: 1372-1379

137 Tseng LM, Chen JY, Won JG, Tseng HS, Yang AH, Wang SE, Lee CH. The role of intra-arterial calcium stimulation test with hepatic venous sampling (IACS) in the management of occult insulinomas. Ann Surg Oncol 2007; 14: 2121-2127

138 Brandle M, Pfammatter T, Spinas GA, Lehmann R, Schmid C. Assessment of selective arterial calcium stimulation and hepatic venous sampling to localize insulin-secreting tumours. Clin Endocrinol (Oxf) 2001; 55: 357-362

139 Christ E, Wild D, Forrer F, Brandle M, Sahli R, Clerici T, Gloor B, Martius F, Maecke H, Reubi JC. Glucagon-like peptide-1 receptor imaging for localization of insulinomas. J Clin Endocrinol Metab 2009; 94: 4398-4405

140 Wild D, Macke H, Christ E, Gloor B, Reubi JC. Glucagon-like peptide 1-receptor scans to localize occult insulinomas. New Engl J Med 2008; 359: 766-768

141 Kulke MH, Bergsland EK, Yao JC. Glycemic control in patients with insulinoma treated with everolimus. New Engl J Med 2009; 360: 195-197

142 Fiebrich HB, Siemerink EJ, Brouwers AH, Links TP, Remkes WS, Hospers $G A$, de Vries EG. Everolimus induces rapid plasma glucose normalization in insulinoma patients by effects on tumor as well as normal tissues. Oncologist 2011; 16: 783-787

143 Leibiger IB, Leibiger B, Moede T, Berggren PO. Exocytosis of insulin promotes insulin gene transcription via the insulin receptor/PI-3 kinase/ p70 s6 kinase and CaM kinase pathways. Mol Cell 1998; 1: 933-938

144 Aspinwall CA, Lakey JR, Kennedy RT. Insulin-stimulated insulin secretion in single pancreatic beta cells. J Biol Chem 1999; 274: 6360-6365

145 Kellogg TA, Bantle JP, Leslie DB, Redmond JB, Slusarek B, Swan T, Buchwald $H$, Ikramuddin $S$. Postgastric bypass hyperinsulinemic hypoglycemia syndrome: characterization and response to a modified diet. Surg Obes Relat Dis 2008; 4: 492-499

146 Moreira RO, Moreira RB, Machado NA, Goncalves TB, Coutinho WF. Post-prandial hypoglycemia after bariatric surgery: pharmacological treatment with verapamil and acarbose. Obes Surg 2008; 18 : $1618-1621$

147 McLaughlin T, Peck M, Holst J, Deacon C. Reversible hyperinsulinemic hypoglycemia after gastric bypass: a consequence of altered nutrient delivery. The J Clin Endocrinol Metab 2010; 95: 1851-1855 